\title{
Biota and geomorphic processes as key environmental factors controlling soil formation at Elephant Point, Maritime Antarctica
}

\author{
A. González-Guzmán ${ }^{\mathrm{a}, *}$, M. Oliva ${ }^{\mathrm{b}}$, V.S. Souza-Júnior ${ }^{\mathrm{c}}$, A. Pérez-Alberti ${ }^{\mathrm{d}}$, J. Ruiz-Fernández ${ }^{\mathrm{e}}$ \\ X.L. Otero ${ }^{\mathrm{f}, g}$ \\ a Departamento de Agronomía, Universidad de Córdoba, Spain \\ b Center for Geographical Studies, IGOT, Universidade de Lisboa, Lisbon, Portugal \\ c Departamento de Agronomía, Área de Solos Universidade Federal Rural de Pernambuco, Brazil \\ d Departamento de Xeografía, Facultade de Xeografía, Universidad de Santiago de Compostela, Spain \\ e Department of Geography, University of Oviedo, Oviedo, Spain \\ ${ }^{\mathrm{f}}$ Departamento de Edafoloxía e Química Agrícola, Facultade de Bioloxía, Universidade de Santiago de Compostela, Spain \\ ${ }^{g}$ Departamento de Tecnología de Ciencia de los Alimentos y Biotecnología, Universidad Politécnica Nacional, Quito, Ecuador
}

\section{A R T I C L E I N F O}

\section{Keywords:}

Maritime Antarctica

Phosphate minerals

Glacial abrasion

Mineralogy

\begin{abstract}
A B S T R A C T
We examined the main soil forming factors affecting the soil composition, soil properties and the associated soilforming processes at Elephant Point, a small ice-free environment in the South Shetland Islands, Maritime Antarctica. For this purpose, we collected twenty soil samples from each of ten different sites distributed along a linear transect running from the coast to the front of the Rotch Dome glacier. The samples were obtained from surface layers $(0-10 \mathrm{~cm})$ and at depth $(40-50 \mathrm{~cm})$, although collection was limited in the moraine area by the permafrost table. We determined $\mathrm{pH}$, electrical conductivity, size particle distribution, total organic carbon, total nitrogen and total concentrations of $\mathrm{Al}, \mathrm{Fe}, \mathrm{Ca}$ and $\mathrm{P}$, for physical and chemical characterization of the samples. We also analysed the samples to determine the bioavailability of nutrients and $\mathrm{Fe}, \mathrm{Al}$ and $\mathrm{P}$ partitioning and finally examined them by isotopic $\left(\delta^{15} \mathrm{~N}\right)$ and X-ray diffraction (XRD) analysis. The results of the analyses revealed two clear geochemical environments corresponding to the two most extensive geomorphological units in this peninsula: moraine and marine terraces. Soils from the moraine were characterized by alkaline reaction and high quantity of minerals with a low degree of crystallinity, whereas soils from the marine terraces showed acid reaction, high concentration of organometallic complexes and a high diversity of phosphate minerals (taranakite, minyulite, struvite, hydroxylapatite and leucophosphite), which seem to be generated by phosphatization of faecal matter deposited by seabirds and seals. Consequently, biota activity is the most relevant soil differentiating factor in the marine terraces, which add organic matter and activate geochemical cycles. On the other hand, geomorphic processes strongly affected by physical weathering processes such as glacial abrasion (by grinding process), frost shattering, and wind abrasion are the main soil-forming factors in moraine. These forces break up the parent material, transform it and translocate the products formed.
\end{abstract}

\section{Introduction}

Knowledge about soil formation and evolution in Antarctica has increased substantially during the last few decades; however, the role of physical and chemical weathering in soil development remains unclear. Some researchers have recently examined the main chemical (Dixon, 2013; Otero et al., 2015a, 2013) and physical (Hall et al., 2002) processes associated with soil formation in cold climates. Among the latter, cryoturbation, wind and stream erosion (Bhatia et al., 2013; Hawkings et al., 2015; Hodson et al., 2004; Wadham et al., 2013), glacial grinding (Cowton et al., 2012; Gengnian et al., 2009; Jari, 1995; Keller and Reesman, 1963a), solifluction (Matsuoka, 2001), sedimentation (Hawkings et al., 2015), salt weathering and freeze-thaw activity (Campbell and Caridge, 1987) are the main processes described, all of which contribute to the heterogeneity of Antarctic soil. Some of the above-mentioned are geomorphic processes which modify the relief and are consequently important soil-forming factors. Moisture conditions are also important in cold regions, and they either limit soil formation (Allen et al., 2001; Thorn et al., 2001) or enhance chemical weathering (Hall, 2004). In areas close to the coast, such as Maritime Antarctica,

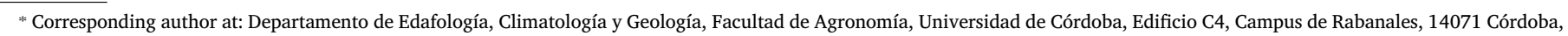
España.

E-mail address: guzman_agg@hotmail.com (A. González-Guzmán). 
chemical weathering may be as important as physical weathering (Anderson et al., 1997; Beyer et al., 2000; Dixon, 2013) and freezethaw cycles are more frequent (de Pablo et al., 2014) than in continental Antarctica (Hall, 1997). Chemical weathering is strongly influenced by living organisms, which must adapt to harsh climatic conditions (Otero et al., 2013). Living organisms depend on the existence of ice free areas, which have increased over the last decades as a result of glacial retreat in Livingston Island (Molina et al., 2007), despite recent deceleration of glacier mass loss in the area (Navarro et al., 2013).

Pioneer biota (mainly microorganisms and plants) modifies and adjusts the substrate, thus improving the conditions for new living organisms colonizing these areas. This can create a positive feedback and accelerate soil formation (Moura et al., 2012; Otero et al., 2015a), especially in summer in Maritime Antarctica areas, including the northern tip of Antarctic Peninsula, where the greater availability of water supports chemical weathering processes (Pereira et al., 2013a, 2013b; Simas et al., 2007; Ugolini, 1972). In addition, seabirds and mammals contribute to the establishment and growth of vegetation and enhance mineral weathering due to the high inputs of organic matter, nitrogen and phosphorus via their faecal matter (Pereira et al., 2013b; Schaefer et al., 2008; Simas et al., 2008). The incorporation of organic matter into the mineral soil strongly influences the formation of clay minerals and secondary phosphates, forming the characteristic ornithogenic soils, which are some of the most well developed soils in Maritime Antarctica (Moura et al., 2012).

The original objective of this study was to examine the combined effects of the parent material (Moraines and Marine Terraces) and time (terraces of different ages) on soil formation processes. For this purpose, we established a sampling transect between the coast and the glacier. After observing that soil properties and soil-forming processes were not greatly affected by either parent material or age of the geomorphological units, we decided to refocus the study aims. The final objectives were therefore to identify the main soil forming factors affecting the soil composition, soil properties and the associated soil-forming processes. We analysed several physical and chemical properties of the soil samples taken along the transect, which follows the deglaciation in the environment, including the two most extensive geomorphological units: marine terraces and moraine (Oliva and Ruiz-Fernández, 2017).

\section{Material and methods}

\subsection{Study area}

The study was carried out at Elephant Point $\left(62^{\circ} 41^{\prime} 12^{\prime \prime} \mathrm{S} ; 60^{\circ} 51^{\prime} 33^{\prime \prime}\right.$ $\mathrm{W}$ ), a small peninsula in the westernmost part of Livingston Island (South Shetland Islands, SSI, Antarctica) (Fig. 1). Livingston Island is one of the largest ice free areas in Antarctica (16\% of the $818 \mathrm{~km}^{2}$ is ice free surface), and Elephant Point is included in this ice-free terrain. In this area, the Rotch Dome glacier was significantly more extensive during the Early-Mid Holocene, covering most of the western fringe of Livingston Island until the Late Holocene (Oliva and Ruiz-Fernández, 2017). Consequently, the current ice-free environment at Elephant Point $\left(1.16 \mathrm{~km}^{2}\right)$ was covered by glacial ice during most of the Holocene. Evidence of this is found in the bedrock plateaus, where some of the blocks are slightly polished and exhibit traces of glacial striae running N-S (Oliva and Ruiz-Fernández, 2015). Subsequently, the glacial retreat that occurred during the Late Holocene, together with the concurrent postglacial isostatic rebound, exposed the low lands of this peninsula, where a sequence of five marine terraces were formed following the glacial retreat (Fretwell et al., 2010; Watcham et al., 2011). The marine terraces thus show a geochronological sequence ranging from 500 years BP (closest to the coast) to 1800 years BP (furthest from the sea) (Table 1). The retreat of the Late Holocene glacier led to formation of a polygenic moraine, with a succession of different ridges due to minor retreats and advances during this time
(Oliva and Ruiz-Fernández, 2015). The age of moraine is not as clear as that of marine terraces, although the moraine is known to have been formed later than the terraces, in the last 1.800 years BP.

Field sampling included both of the above-mentioned geomorphological units: marine terraces (MT) and moraine (M). The first five sampling sites correspond to the five marine terraces. The first terrace formed was the farthest from the sea, represented by sample EP5, and the most recent terrace is represented by sample EP1 (closest to the sea) (Table 1 and Fig. 1). The other five sampling sites were further from the sea, in the moraine, and the furthest site (EP10) was very close to Rotch Dome glacier ( $3 \mathrm{~m}$ away). The elevation from the sampling sites ranged from sea level to $55 \mathrm{~m} \cdot$ a.s.l. at the internal moraine ridge (Table 1) (Oliva and Ruiz-Fernández, 2017).

\subsection{Environmental setting}

The climatic conditions at Elephant Point are characteristic of polar oceanic environments. The mean temperature between 2002 and 2010 in the nearby Byers Peninsula was $-2.8^{\circ} \mathrm{C}$ at 70 ma.s.l., and the annual precipitation oscillated between 500 and $800 \mathrm{~mm}$, mostly concentrated during the summer season and falling either as rain or snow (Bañón et al., 2013). Freeze-thaw cycles in the ground are also more frequent during this season (de Pablo et al., 2014).

These SSI (South Shetland Islands) are calc-alkaline island arcs (Lee et al., 2004) and are mainly formed by schists, basalts, dacites, conglomerates, rhyolites and andesite (Smellie et al., 1984). The lithology of Elephant Point is mainly formed by weathered basalts, schist, some granodiorites and some shales found in moraine sediments, which are mobilized down-slope by slow mass-wasting processes (Oliva and Ruiz-Fernández, 2017).

Vegetation cover is very sparse and predominantly occurs on the flat marine terraces, where seabirds are present and where they are protected from the wind and from the trapping of penguins (Vera, 2011; Victoria et al., 2013).

The predominant vegetation forms comprise mosses (Andreaea gainii, Calliergon sarmentosum, Calliergidium austro-stramineum), lichens (Usnea antarctica, Usnea aurantiaco-atra, Rhizocarpon geographicum) and two native vascular plants (Deschampsia antarctica and Colobanthus quitensis).

\subsection{Soil sampling}

The initial purpose was to identify any trends in the soil properties relative to the age of the terraces, parent material and the distance from the glacier in the moraine environment. For this purpose, a linear transect was sampled from coast to the glacier in late January 2014 and twenty soil samples were obtained at ten different representative sites at Elephant Point peninsula. Finally, this type of design enabled identification of the main soil-forming factors in the field as well as the associated soil forming processes.

In MT one sampling point was established in each terrace, and in M the same number of sampling points was established at different distances from the glacier. Two samples were taken at each sample point: one from the surface $\left(\mathrm{EP}_{\mathrm{S}}: 0-10 \mathrm{~cm}\right)$ and the other at depth $\left(\mathrm{EP}_{\mathrm{D}}\right.$ : 40-50 cm), (Table 1). In accordance with Bockheim et al. (2013), Ramos et al. (2009), Serrano et al. (2008) and Vieira et al. (2010), continuous permafrost was only found in moraine at elevations higher than 30-40 ma.s.l. However, in MT the compact material was the factor limiting the depth of the sample, which was very homogeneous. The soil samples were stored in PVC boxes until being transported to the laboratory.

\subsection{Soil analysis}

All samples were sieved through a mesh of $2 \mathrm{~mm}$ pore size and analysed in duplicate. 


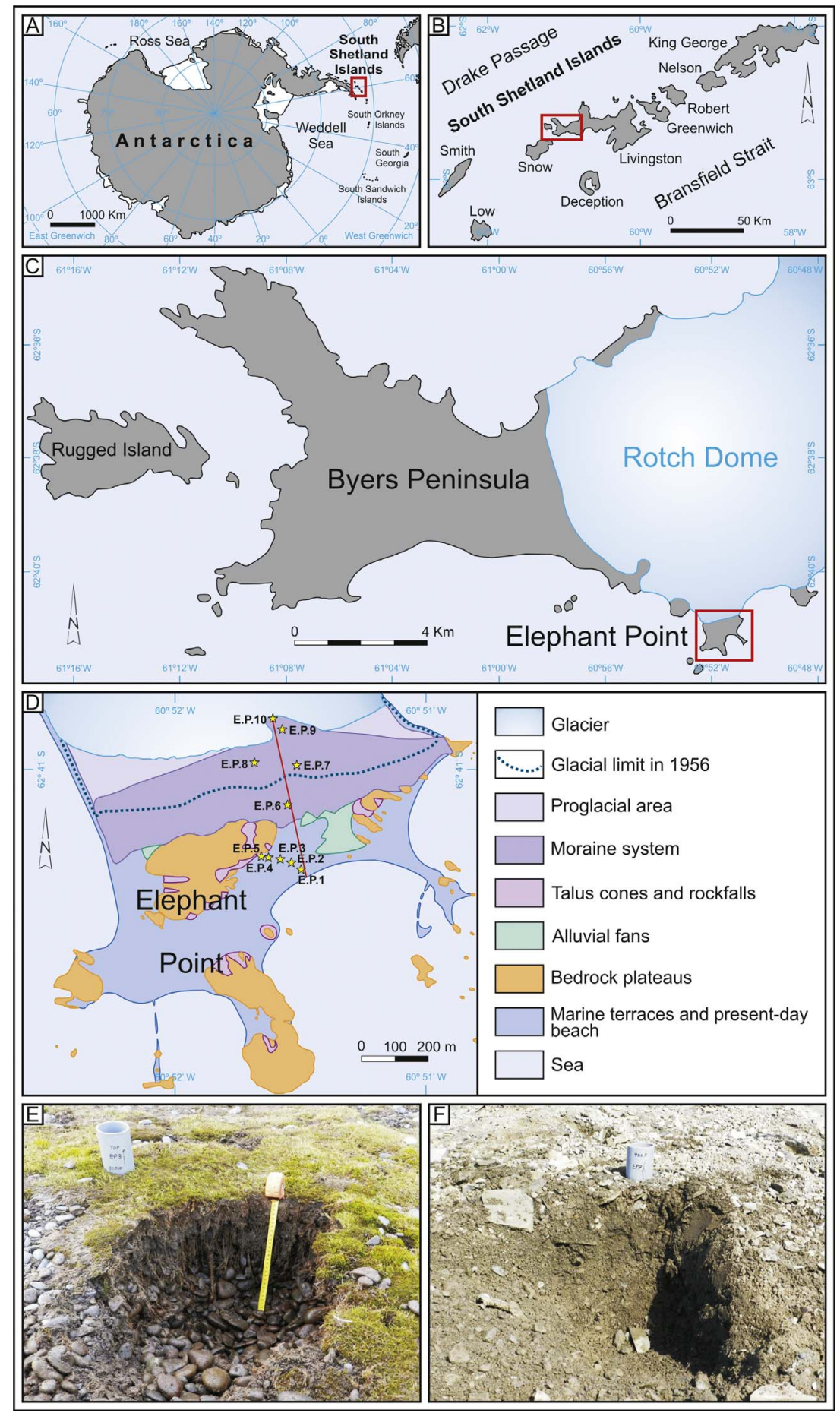

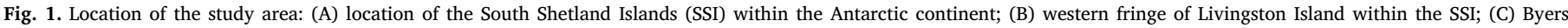

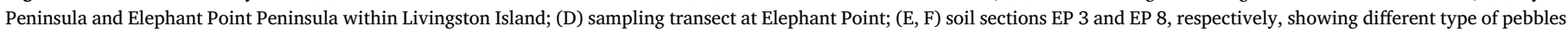
on the ground. Rounded pebbles are frequent on the marine terraces, and angular to subangular pebbles are found on the moraine.

\subsubsection{Physical and chemical analysis}

The $\mathrm{pH}$ was determined in water $\left(\mathrm{pH}_{\mathrm{w}}\right)$ and in $0.1 \mathrm{M} \mathrm{KCl}\left(\mathrm{pH}_{\mathrm{KCl}}\right)$, at a ratio of 1:2.5 (Rowell, 1994), and in $\mathrm{NaF} 1 \mathrm{M}\left(\mathrm{pH}_{\mathrm{NaF}}\right)$, at a ratio of $1: 50$, for $2 \mathrm{~min}$. Abrasion $\mathrm{pH}\left(\mathrm{pH}_{\text {abrasion }}\right)$ was determined in the sand fraction. For this purpose, $25 \mathrm{~mL}$ of distilled water was added to $10 \mathrm{~g}$ of grinded sand (previously washed with Milli-Q water) (Ferrari and Magaldi, 1983). Particle size was determined by the pipette method (Gee and Bauder, 1986). The total organic carbon (TOC), after removal of carbonates with $10 \% \mathrm{HCl}$, and total nitrogen (TN) were measured in a LECO CNS-2000 autoanalyzer. The total amounts of Fe (TFe), Al (TAl), P (TP), P sand fraction ( $\mathrm{TP}_{\text {sand }}$ ) and $\mathrm{Ca}$ (TCa) were extracted in an Ethos Plus microwave lab station by adding $12 \mathrm{~mL}$ of a mixture of $\mathrm{HNO}_{3} / \mathrm{HCl}(3: 9, \mathrm{v} / \mathrm{v})$. The efficiency of the extraction process ( $\left.>90 \%\right)$ was determined by analysis of certified reference material (Soil SO3).

Three fractions of iron and two of aluminium were extracted: 1) Fe and $\mathrm{Al}$ extracted with $0.1 \mathrm{M}$ sodium pyrophosphate $\left(\mathrm{Fe}_{\text {pyro }}\right.$ and $\left.\mathrm{Al}_{\text {pyro }}\right)$ (Bascomb, 1968); 2) $\mathrm{Fe}$ and $\mathrm{Al}$ extracted with $0.2 \mathrm{M}$ acid ammonium oxalate at pH $3\left(\mathrm{Al}_{\text {oxa }}\right.$ and $\left.\mathrm{Fe}_{\text {oxa }}\right)$ (Blakemore, 1983); and 3) Fe extracted 
Table 1

Geographical description of the sampling sites, together with a general description of the soil sections.

\begin{tabular}{|c|c|c|c|c|c|c|}
\hline Sample & Depth $(\mathrm{cm})$ & Unit & $\begin{array}{l}\text { Elevation } \\
\text { (m a.s.l) }\end{array}$ & Vegetation cover & Geographical Coordinates & Texture, field observations and age of terraces \\
\hline EP 1S & $<10$ & MT 5 & 4 & $\approx 10 \%$ & $62^{\circ} 41^{\prime} 12.1^{\prime \prime} \mathrm{S}$ & Sandy loam. Presence of small lichens and mosses on the surface. Formed over \\
\hline EP 1D & $\approx 40$ & & & & $60^{\circ} 51^{\prime} 33.0^{\prime \prime} \mathrm{W}$ & $500 \mathrm{cal} \cdot \mathrm{yr} \mathrm{BP}$ \\
\hline EP 2S & $<10$ & MT 4 & 9 & $\approx 30 \%$ & $62^{\circ} 41^{\prime} 11.0^{\prime \prime} \mathrm{S}$ & Loamy sand and sand respectively. Higher organic matter content, mosses and little \\
\hline EP 2D & $\approx 45$ & & & & $60^{\circ} 51^{\prime} 35.0^{\prime \prime} \mathrm{W}$ & roots. Formed over $1.2 \mathrm{ka}$ cal BP \\
\hline EP 3S & $<10$ & MT 3 & 11 & $\approx 50 \%$ & $62^{\circ} 41^{\prime} 10.4^{\prime \prime} \mathrm{S}$ & Loamy sand. Presence of rounded pebbles. Flat terrain, flooded during some periods. \\
\hline EP 3D & $\approx 45$ & & & & $60^{\circ} 51^{\prime} 36.2^{\prime \prime} \mathrm{W}$ & Formed over $1.8 \mathrm{ka} \mathrm{cal} \mathrm{BP}$ \\
\hline $\mathrm{EP} 4 \mathrm{~S}$ & $<10$ & MT 2 & 12 & $\approx 40 \%$ & $62^{\circ} 41^{\prime} 10.0^{\prime \prime} \mathrm{S}$ & Sandy. Presence of roots and grey material. Close to semipermanent lagoons. Formed \\
\hline EP 4D & $\approx 40$ & & & & $60^{\circ} 51^{\prime} 37.6^{\prime \prime} \mathrm{W}$ & over $1.8 \mathrm{ka} \mathrm{cal} \mathrm{BP}$ \\
\hline EP 5S & $<10$ & MT 1 & 16 & $\approx 35 \%$ & $62^{\circ} 41^{\prime} 9.9^{\prime \prime} \mathrm{S}$ & Sandy. Rounded pebbles in a sandy matrix. Close to an elephant seal colony. Formed \\
\hline EP 5D & $\approx 45$ & & & & $60^{\circ} 51^{\prime} 38.8^{\prime \prime} \mathrm{W}$ & over $1,8 \mathrm{ka} \mathrm{cal} \mathrm{BP}$ \\
\hline EP 6S & $<10$ & M & 18 & $\approx 5 \%$ & $62^{\circ} 41^{\prime} 5.9^{\prime \prime} \mathrm{S}$ & Sandy loam. Presence of angular pebbles next to the moraine slope \\
\hline EP 6D & $\approx 45$ & & & & $60^{\circ} 51^{\prime} 34.3^{\prime \prime} \mathrm{W}$ & \\
\hline EP 7S & $<10$ & M & 55 & $0 \%$ & $62^{\circ} 41^{\prime} 2.7^{\prime \prime} \mathrm{S}$ & Sandy loam. No differences between horizons were observed in this homogeneous soil \\
\hline EP 7D & $\approx 55$ & & & & $60^{\circ} 51^{\prime} 34.1^{\prime \prime} \mathrm{W}$ & section collected from the external moraine ridge. \\
\hline EP 8S & $<10$ & M & 55 & $0 \%$ & $62^{\circ} 41^{\prime} 1.0^{\prime \prime} \mathrm{S}$ & Sandy loam. These samples were collected from the internal moraine. Evidence of \\
\hline EP 8D & $\approx 45$ & & & & $60^{\circ} 51^{\prime} 38.4^{\prime \prime} \mathrm{W}$ & glacial abrasion and recent slope activity remobilizing sediments \\
\hline EP 9S & $<10$ & M & 28 & $0 \%$ & $62^{\circ} 40^{\prime} 55.8^{\prime \prime} \mathrm{S}$ & Sandy loam. High moisture content due to snow melting and thawing of the active \\
\hline EP 9D & $\approx 45$ & & & & $60^{\circ} 51^{\prime} 35.6^{\prime \prime} \mathrm{W}$ & layer \\
\hline EP $10 \mathrm{~S}$ & $<10$ & M & 26 & $0 \%$ & $62^{\circ} 40^{\prime} 52.9^{\prime \prime} \mathrm{S}$ & Sandy loam. Humid environment located only $3 \mathrm{~m}$ from the glacier front \\
\hline EP 10D & $\approx 45$ & & & & $60^{\circ} 51^{\prime} 36.8^{\prime \prime} \mathrm{W}$ & \\
\hline
\end{tabular}

with sodium dithionite - citrate-bicarbonate $\left(\mathrm{Fe}_{\mathrm{dit}}\right)$ (Mehra and Jackson, 1960). The fractions are considered indicators of different compounds, as follows:

- $\mathrm{Fe}_{\text {pyro }}$ and $\mathrm{Al}_{\text {pyro }}$ provide an estimate of the metallo-organic complexes (Bascomb, 1968);

- $\mathrm{Fe}_{\text {oxa }}-\mathrm{Fe}_{\mathrm{pyro}}$ provide an estimate of amorphous iron oxides $\left(\mathrm{Fe}_{\text {amorp }}\right)$ (Blakemore, 1983);

- $\mathrm{Al}_{\text {oxa }}-\mathrm{Al}_{\text {pyro }}$ provide an estimate of amorphous aluminium oxides $\left(\mathrm{Al}_{\mathrm{amorp}}\right)$ (Blakemore, 1983).

- $\mathrm{Fe}_{\mathrm{dit}}-\mathrm{Fe}_{\text {oxa }}$ provides an estimate of crystalline iron oxyhydroxides ( $\mathrm{Fe}_{\text {crys }}$ ) (Mehra and Jackson, 1960).

The concentration of $\mathrm{C}$ in the pyrophosphate extracts was also determined by a modified version of the method described by Walkley and Black (1934).

Bioavailable macro (P, $\mathrm{Ca}, \mathrm{Mg}, \mathrm{K}$ ) and micronutrients ( $\mathrm{Fe}, \mathrm{Co}, \mathrm{Cu}$, $\mathrm{Zn}$ and Ni) were extracted with Mehlich 3 extractant (Mehlich, 1984).

Simulation of glacial abrasion by grinding was studied by carrying out a small experiment (Keller and Reesman, 1963a). The sand was separated from eight samples (4 from MT and 4 from M, chosen randomly). The sand was then washed with Milli-Q water and an equal portion of each was ground in a mortar. The ground and unground sand samples were extracted with ammonium oxalate at $\mathrm{pH} 3$ to enable comparison of the concentration of low crystalline phases in each (Blakemore, 1983).

For $\delta^{15} \mathrm{NN}$ analysis, 8 samples were chosen randomly (4 from MT and 4 from $\mathrm{M}$ ). The samples were combusted in an elemental autoanalyzer FlashEA1112 (ThermoFinnigan) and the isotope ratios were determined in a mass spectrophotometer (Deltaplus, ThermoFinnigan).

Partitioning of solid-phase $\mathrm{P}$ was determined in fresh samples $(2 \mathrm{~g})$ by a sequential extraction method that enable identification of six operationally defined $\mathrm{P}$ fractions, which are described as follows (Paludan and Jensen, 1995; Paludan and Morris, 1999):

1. Adsorbed P: the most labile and reactive phosphorus (stirring $1 \mathrm{~h}$ with Milli-Q water).

2. P-Fe: the $\mathrm{P}$ associated with reducible $\mathrm{Fe}$ and $\mathrm{Mn}$ oxyhydroxides (stirring with $0.11 \mathrm{M} \mathrm{NaHCO}_{3}$ and $0.11 \mathrm{M} \mathrm{Na}_{2} \mathrm{~S}_{2} \mathrm{O}_{4}$ for $1 \mathrm{~h}$ ).

3. P-Al/Clay: the fraction associated with aluminium and clays (stirring with $\mathrm{NaOH} 0.1 \mathrm{M}$ for $1 \mathrm{~h}$ ).
4. P-HA: the fraction bound to humic acids (HA) (extracted by precipitation of the $\mathrm{HA}$ in the $\mathrm{P}-\mathrm{Al} /$ Clay supernatant with sulphuric acid, filtration, burning at $520^{\circ} \mathrm{C}$ and digestion with $\mathrm{HCl} 1 \mathrm{M}$ at $>90^{\circ} \mathrm{C}$ for at least $10 \mathrm{~min}$ ).

5. P-Ca: the phosphorus associated with calcium (by stirring the residue from $\mathrm{P}-\mathrm{Al} / \mathrm{Clay}$ with $\mathrm{HCl} 1 \mathrm{M}$ for $1 \mathrm{~h}$ ).

6. P-Residual: the phosphorus bound to recalcitrant compounds as organic matter or which is contained in sand with larger particles (ignition of the residue of $\mathrm{P}-\mathrm{Ca}$ at $520{ }^{\circ} \mathrm{C}$ and subsequent digestion with $\mathrm{HCl} 1 \mathrm{M}$ at $>90^{\circ} \mathrm{C}$ for $10 \mathrm{~min}$ ).

In all extraction steps, the residue was washed twice with $50 \mathrm{~mL}$ of Milli-Q water and centrifuged at $6000 \mathrm{rpm}$ for $15 \mathrm{~min}\left(4^{\circ} \mathrm{C}\right)$ to clean any possible residues from the previous extraction.

The contents of $\mathrm{Fe}, \mathrm{Al}, \mathrm{Ca}, \mathrm{Mg}, \mathrm{K}, \mathrm{Co}, \mathrm{Cu}$, and $\mathrm{Zn}$ were quantified by atomic absorption spectrometry (PERKIN ELMER 1100B), while P was measured in a spectrophotometer following the procedure described by Murphy and Riley (1962).

\subsubsection{Mineralogy}

Mineralogical analysis was carried out on clay $(<2 \mu \mathrm{m})$, silt $(0.05-0.002 \mathrm{~mm})$ and coarse sand fractions $(2-1 \mathrm{~mm})$ by X-ray diffraction (XRD). The sand and silt plus clay fractions were then separated by moist sieving and the silt and clay were then separated by decantation (Jackson, 1979). X-ray diffraction (XRD) analysis was carried out on glass slides for oriented aggregates of the clay fraction saturated with $\mathrm{Mg}^{2+}$, and for random powder mounts of unsaturated clays, silt and sand (fine and coarse) fractions. The $\mathrm{Mg}^{2}+$ saturated samples were processed as oriented aggregates $(\mathrm{Mg})$ and also solvated in glycerol (Mg-Gli). These sample were also analysed after heating for $3 \mathrm{~h}$ at $550{ }^{\circ} \mathrm{C}$ and $700{ }^{\circ} \mathrm{C}$ (Mg-K550 and Mg-700) (Jackson, 1979).

The XRD patterns were obtained with a Shimadzu XRD 6000 diffractometer (Shimadzu Corporation, Tokyo), using $\mathrm{Cu}-\mathrm{K} \alpha$ radiation, with a graphite monochromator and applying $40 \mathrm{kV}$ and a $30 \mathrm{~mA}$ current, with a velocity of $1.0^{\circ} 2 \theta \mathrm{min}^{-1}$ and a step size of $0.02^{\circ} 2 \theta$. The analyses were conducted in the range $2-40^{\circ} 2 \theta$ for oriented aggregates and $3-70^{\circ} 2 \theta$ for random powder.

\subsubsection{Statistical analysis}

Owing to the lack of a clear continuous gradient in relation to the age of the terraces and the distance from the glacier, we decided to group the data into four data sets for each main geomorphological unit 
Table 2

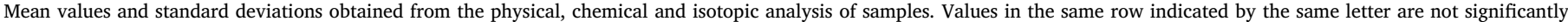

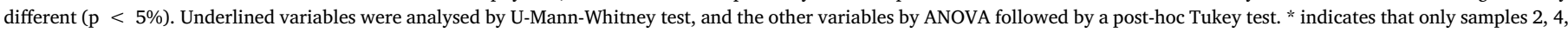
7 and 9 were analysed and ** indicates that only samples 4, 5, 7 and 9 were analysed.

\begin{tabular}{|c|c|c|c|c|c|c|c|c|c|}
\hline \multirow[t]{2}{*}{ Variable } & \multirow[t]{2}{*}{ Unit } & \multicolumn{2}{|c|}{ MT surface } & \multicolumn{2}{|c|}{ MT depth } & \multicolumn{2}{|c|}{ M surface } & \multicolumn{2}{|l|}{ M depth } \\
\hline & & Mean & $\sigma$ & Mean & $\sigma$ & Mean & $\sigma$ & Mean & $\sigma$ \\
\hline $\mathrm{pH}_{\mathrm{w}}$ & & 5.3 & $0.8 \mathrm{a}$ & 5.2 & $0.9 \mathrm{a}$ & 8.1 & $0.4 \mathrm{~b}$ & 8.2 & $0.2 \mathrm{~b}$ \\
\hline $\mathrm{pH}_{\mathrm{KCl}}$ & & 4.2 & $0.3 \mathrm{a}$ & 4.1 & $0.4 \mathrm{a}$ & 6.7 & $0.4 \mathrm{~b}$ & 6.9 & $0.3 \mathrm{~b}$ \\
\hline $\mathrm{pH}_{\mathrm{NaF}}$ & & 8.6 & $0.3 \mathrm{a}$ & 8.8 & $0.5 \mathrm{ab}$ & 9.3 & $0.2 \mathrm{~b}$ & 9.3 & $0.2 \mathrm{~b}$ \\
\hline $\mathrm{pH}_{\text {abrasion }}{ }^{*}$ & & 8.3 & $0.1 \mathrm{a}$ & 8.3 & $1.1 \mathrm{a}$ & 8.3 & $0.0 \mathrm{a}$ & 8.1 & $0.1 \mathrm{a}$ \\
\hline$\underline{\text { Sand }}$ & $\%$ & 84 & $8 \mathrm{a}$ & 80 & $18 \mathrm{ab}$ & 63 & $6 \mathrm{~b}$ & 66 & $6 \mathrm{~b}$ \\
\hline$\underline{\text { Silt }}$ & $\%$ & 11 & $7 \mathrm{a}$ & 16 & $17 \mathrm{ab}$ & 27 & $5 \mathrm{~b}$ & 26 & $5 \mathrm{~b}$ \\
\hline$\overline{\text { Clay }}$ & $\%$ & 5 & $3 \mathrm{ac}$ & 3 & $1 \mathrm{a}$ & 10 & $3 \mathrm{~b}$ & 8 & $1 \mathrm{bc}$ \\
\hline TOC & $\%$ & 1.27 & $0.81 \mathrm{a}$ & 0.64 & $0.27 \mathrm{ab}$ & 0.18 & $0.02 \mathrm{~b}$ & 0.16 & $0.01 \mathrm{~b}$ \\
\hline $\mathrm{C}_{\text {pyro }}$ & $\%$ & 0.68 & $0.45 \mathrm{a}$ & 0.50 & $0.40 \mathrm{a}$ & 0.16 & $0.04 \mathrm{a}$ & 0.15 & $0.02 \mathrm{a}$ \\
\hline $\mathrm{TN}$ & $\%$ & 0.13 & $0.08 \mathrm{a}$ & 0.05 & $0.03 \mathrm{a}$ & 0.01 & $0.01 \mathrm{~b}$ & $<$ L.D & \\
\hline$\delta^{15} \mathrm{~N}^{* *}$ & $\% 0$ & 15.4 & 3.3 & 15.3 & 0.3 & 4.4 & 2.0 & 7.1 & 1.1 \\
\hline Conductivity & $\mu \mathrm{Scm}^{-1}$ & 169 & $138 \mathrm{a}$ & 61 & $45 \mathrm{a}$ & 86 & $52 \mathrm{a}$ & 53 & $19 \mathrm{a}$ \\
\hline$\underline{F e}_{\text {pyro }}$ & $\mathrm{mgKg}^{-1}$ & 2754 & $1072 \mathrm{a}$ & 4122 & $2720 \mathrm{a}$ & 147 & $52 \mathrm{~b}$ & 319 & $368 \mathrm{~b}$ \\
\hline $\mathrm{Al}_{\text {pyro }}$ & $\mathrm{mgKg}^{-1}$ & 989 & 307 a & 1028 & 775 a & 60 & $70 \mathrm{~b}$ & 68 & $11 \mathrm{~b}$ \\
\hline$\underline{\mathrm{Fe}_{\text {amorp }}}$ & $\mathrm{mgKg}^{-1}$ & 3957 & $1004 \mathrm{a}$ & 4041 & 1327 a & 4272 & $465 \mathrm{a}$ & 3956 & $642 \mathrm{a}$ \\
\hline $\mathrm{Al}_{\text {amorp }}$ & $\mathrm{mgKg}^{-1}$ & 3132 & 291 a & 3113 & 1576 a & 7479 & $614 \mathrm{~b}$ & 6937 & $1018 \mathrm{~b}$ \\
\hline $\mathrm{Fe}_{\text {crys }}$ & $\mathrm{mgKg}^{-1}$ & 3922 & $2662 \mathrm{a}$ & 2942 & $2402 \mathrm{a}$ & 2998 & $340 \mathrm{a}$ & 3052 & 508 a \\
\hline$\underline{\mathrm{TFe}}$ & $\mathrm{mgKg}^{-1}$ & 49,360 & 13,439 a & 42,960 & 11,475 a & 53,400 & $3209 \mathrm{a}$ & 52,600 & $1816 \mathrm{a}$ \\
\hline$\overline{\mathrm{TAl}}$ & $\mathrm{mgKg}^{-1}$ & 29,800 & $7959 \mathrm{ab}$ & 25,680 & $11,576 \mathrm{a}$ & 41,560 & $4245 \mathrm{~b}$ & 40,640 & $2923 \mathrm{~b}$ \\
\hline$\underline{\mathrm{TCa}}$ & $\mathrm{mgKg}^{-1}$ & 33,385 & $6137 \mathrm{a}$ & 29,502 & 8954 a & 48,697 & $1871 \mathrm{~b}$ & 48,081 & $2258 \mathrm{~b}$ \\
\hline$\overline{\mathrm{P}_{\mathrm{Meh}}}$ & $\mathrm{mgKg}^{-1}$ & 445 & 157 a & 408 & $102 \mathrm{a}$ & 53 & $38 \mathrm{~b}$ & 69 & $33 \mathrm{~b}$ \\
\hline$\underline{\mathrm{Co}}_{\mathrm{Meh}}$ & $\mathrm{mgKg}^{-1}$ & 0.23 & $0.08 \mathrm{a}$ & 0.21 & $0.13 \mathrm{a}$ & 0.45 & $0.12 \mathrm{~b}$ & 0.45 & $0.14 \mathrm{~b}$ \\
\hline $\mathrm{Zn}_{\mathrm{Meh}}$ & $\mathrm{mgKg}^{-1}$ & 0.46 & $0.32 \mathrm{a}$ & 0.30 & $0.34 \mathrm{a}$ & 1.42 & $0.77 \mathrm{~b}$ & 0.80 & $0.34 \mathrm{~b}$ \\
\hline $\mathrm{Cu}_{\mathrm{Meh}}$ & $\mathrm{mgKg}^{-1}$ & 2.44 & $3.46 \mathrm{a}$ & 1.74 & $2.45 \mathrm{a}$ & 5.62 & $1.34 \mathrm{a}$ & 4.84 & $1.42 \mathrm{a}$ \\
\hline $\mathrm{Ni}_{\mathrm{Meh}}$ & $\mathrm{mgKg}^{-1}$ & 0.17 & $0.04 \mathrm{a}$ & 0.11 & $0.08 \mathrm{a}$ & 0.29 & $0.05 \mathrm{a}$ & 0.31 & $0.19 \mathrm{a}$ \\
\hline $\mathrm{Ca}_{\mathrm{Meh}}$ & $\mathrm{mgKg}^{-1}$ & 453 & 399 a & 300 & $415 \mathrm{a}$ & 2987 & $650 \mathrm{~b}$ & 2948 & $667 \mathrm{~b}$ \\
\hline$\underline{\mathrm{Mgeh}}$ & $\mathrm{mgKg}^{-1}$ & 111 & $87 \mathrm{a}$ & 92 & $127 \mathrm{a}$ & 216 & $35 \mathrm{a}$ & 207 & $43 \mathrm{a}$ \\
\hline$\underline{\mathrm{K}}_{\mathrm{Meh}}$ & $\mathrm{mgKg}^{-1}$ & 228 & $174 \mathrm{a}$ & 133.4 & $86 \mathrm{a}$ & 108 & $24 \mathrm{a}$ & 91 & $33 \mathrm{a}$ \\
\hline$\underline{\mathrm{Fe}_{\mathrm{Meh}}}$ & $\mathrm{mgKg}^{-1}$ & 37.0 & $5.5 \mathrm{a}$ & 42.8 & $9.8 \mathrm{a}$ & 34.2 & $2.9 \mathrm{a}$ & 31.8 & $5.2 \mathrm{a}$ \\
\hline Soluble-P & $\mathrm{mgKg}^{-1}$ & 1.60 & $2.20 \mathrm{a}$ & 0.86 & $1.20 \mathrm{a}$ & 1.60 & $2.73 \mathrm{a}$ & 1.72 & $3.22 \mathrm{a}$ \\
\hline $\mathrm{P}-\mathrm{Fe}$ & $\mathrm{mgKg}^{-1}$ & 319 & $121 \mathrm{a}$ & 398 & $180 \mathrm{a}$ & 29 & $29 \mathrm{~b}$ & 34 & $26 \mathrm{~b}$ \\
\hline P-Al/Clay & $\mathrm{mgKg}^{-1}$ & 1127 & $665 \mathrm{ab}$ & 1605 & 1051 a & 117 & $56 \mathrm{~b}$ & 133 & $36 \mathrm{~b}$ \\
\hline P-HA & $\mathrm{mgKg}^{-1}$ & 104 & $15 \mathrm{a}$ & 113 & $48 \mathrm{a}$ & 18 & $10 \mathrm{~b}$ & 22 & $8 \mathrm{~b}$ \\
\hline$\underline{\mathrm{P}-\mathrm{Ca}}$ & $\mathrm{mgKg}^{-1}$ & 421 & $104 \mathrm{a}$ & 434 & $140 \mathrm{a}$ & 535 & $32 \mathrm{a}$ & 553 & $66 a$ \\
\hline$P_{\text {residual }}$ & $\mathrm{mgKg}^{-1}$ & 165 & $45 \mathrm{ab}$ & 171 & $68 \mathrm{a}$ & 86 & $13 \mathrm{~b}$ & 84 & $15 \mathrm{~b}$ \\
\hline $\mathrm{TP}_{\text {Sand }}$ & $\mathrm{mgKg}^{-1}$ & 863 & $123 \mathrm{a}$ & 816 & $407 \mathrm{a}$ & 649 & 79 a & 640 & $98 \mathrm{a}$ \\
\hline$\underline{\mathrm{TP}}$ & $\mathrm{mgKg}^{-1}$ & 2727 & $1174 \mathrm{a}$ & 2631 & 1133 a & 1207 & $187 \mathrm{~b}$ & 1273 & $132 \mathrm{~b}$ \\
\hline
\end{tabular}

and also considering their depth $\left(\mathrm{MT}_{\mathrm{s}}, \mathrm{MT}_{\mathrm{d}}, \mathrm{M}_{\mathrm{s} .}\right.$, and $\mathrm{M}_{\mathrm{d}}$ ) (Table 2). To search for any differences between the two principal geomorphologic areas at Elephant Point and to identify any differences between the samples taken at different depths, we applied ANOVA, the Shapiro-Wilk test and Levene's test (for normally distributed, homoscedastic data) or a non-parametric U-Mann Whitney test (for non normally distributed data). ANOVA was followed by a Tukey test for comparison of all data sets. Differences were considered significant at $\mathrm{p}<0.05$. We also applied Principal Component Analysis (PCA) by implementing a Direct Oblimin test for correlated components. This test enables identification of groups of variables that are correlated with each and with the two main geomorphological units (Fig. 7). The factor scores values (FSV) were calculated for sampling points. We used the 2.0 SPSS statistical software package to carry out all statistical tests, as described by Pallant (2011) and Jolliffe (2002).

\section{Results}

\subsection{General characterization of soils}

We did not observe any relationships between soil properties in marine terraces and their ages or between the soil properties in moraine sampling points and the distance from the glacier. The soil composition and properties were very homogeneous in both geomorphological units (marine terraces and moraine). There were no significant differences between either $\mathrm{MT}_{s}$ and $\mathrm{MT}_{\mathrm{d}}$ or between $\mathrm{M}_{s}$ and $\mathrm{M}_{\mathrm{d}}$ samples. We therefore mainly report and discuss the mean values of the different geomorphological units, taking into account the different depth of samples (Table 2). The description of faecal matter was not taken into account because there was no clear evidence of its presence in MT at the time of the sampling and in $\mathrm{M}$ there are no seabird or seal colonies and therefore no faecal matter.

The soils were of coarse texture, varying between sandy and sandy loam. The MT soils were of coarser texture than the M soils (82, 14 and $4 \%$ compared with 65,26 and $9 \%$ of sand, silt and clay respectively), and the most notable difference was in the clay fraction (Tables 1 and 2).

Mean $\mathrm{pH}$ values $\left(\mathrm{pH}_{\mathrm{w}}\right.$ and $\left.\mathrm{pH}_{\mathrm{KCl}}\right)$ differed significantly between the two groups of soils considered (Table 2, Fig. 2A). The MT soil was acidic $\left(\mathrm{MT}_{\mathrm{S}}: \mathrm{pH}_{\mathrm{w}} 5.3 \pm 0.8\right.$ and $\mathrm{MT}_{\mathrm{D}}: \mathrm{pH}_{\mathrm{w}} 5.2 \pm 0.9$ ), whereas the $\mathrm{M}$ soil was slightly alkaline $\left(\mathrm{M}_{\mathrm{S}}: \mathrm{pH}_{\mathrm{w}} 8.1 \pm 0.4\right.$ and $\left.\mathrm{M}_{\mathrm{D}}: \mathrm{pH}_{\mathrm{w}} 8.2 \pm 0.2\right)$. The $\mathrm{pH}_{\mathrm{NaF}}$ values were higher than 8 and electric conductivity was always very low $\left(<150 \mu \mathrm{S} \cdot \mathrm{cm}^{-1}\right)$, indicating a low ionic concentration in soil solution (Table 2).

The TOC in the MT soil ranged between $0.22 \%$ and $2.53 \%$, and in the $\mathrm{M}$ soil between 0.14 and $0.21 \%$ (Table 2, and Fig. 2B). The mean concentration of $\mathrm{C}_{\text {pyro }}$ was also higher in the MT soil (0.08-1.32\%) than in the $\mathrm{M}$ soil (0.13-0.22\%) and also was higher in the surface samples $\left(\mathrm{EP}_{\mathrm{S}}\right)$ than in the deeper samples $\left(\mathrm{EP}_{\mathrm{D}}\right)$ (Table 2, Fig. $\left.2 \mathrm{~B}\right)$. The TN concentration followed the same pattern as TOC and these variables were strongly positively correlated in each geomorphological unit (MT: $\left.\mathrm{r}_{\mathrm{s}}=0.95, \mathrm{p}<0,001 ; \mathrm{M}: \mathrm{r}_{\mathrm{s}}=0.679 \mathrm{p}<0.05\right)$. The TN concentration ranged from $0.01 \%$ to $0.25 \%$ in MT and from below the limit detection to $0.02 \%$ in $\mathrm{M}$. The $\delta^{15} \mathrm{~N}$ values were very similar in the different 

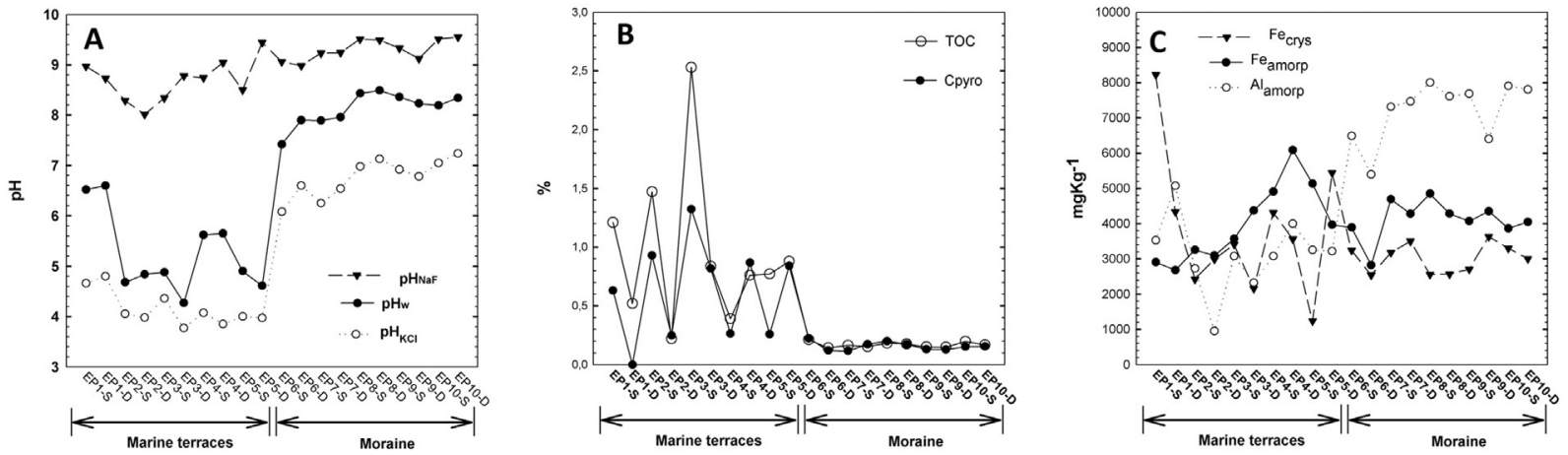

Fig. 2. Spatial variation in the transect of $\mathrm{TOC}$ and $\mathrm{C}_{\mathrm{pyro}}(\mathrm{A}) ; \mathrm{pH}_{\mathrm{w}}, \mathrm{pH}_{\mathrm{KCl}}, \mathrm{pH}_{\mathrm{NaF}}(\mathrm{B}) ; \mathrm{Fe}_{\text {amorp }}, \mathrm{Al}_{\text {amorp }}$ and $\mathrm{Fe}_{\text {crys }}(\mathrm{C})$.

marine terraces and even at depth, reaching values of $17.7 \%$, with the lowest being 13\%o. The values for M soil were lower, being around 3 times lower than for MT (Table 2).

Spatially, TCa, TAl and TFe showed differences, and the concentrations increased upslope towards the moraine (Table 2). Total Ca differed significantly between the two types of soil, and TAl only differed significantly between $\mathrm{MT}_{\mathrm{D}}$ and $\mathrm{M}$. TFe was more homogeneously distributed (Table 2).

The concentrations of metals extracted in sodium pyrophosphate were higher in MT than in $\mathrm{M}$ soils. The concentrations of $\mathrm{Fe}_{\mathrm{pyro}}$ were lower in surface than in deeper samples (2754 and $4122 \mathrm{mg} \mathrm{Kg}^{-1}$, respectively) as in $\mathrm{M}\left(147\right.$ and $\left.319 \mathrm{mg} \cdot \mathrm{Kg}^{-1}\right)$. $\mathrm{Al}_{\text {pyro }}$ followed the same pattern as $\mathrm{Fe}$ (Table 2). On the other hand, neither $\mathrm{Fe}_{\text {amorp }}$ or $\mathrm{Fe}_{\text {crys }}$ were as homogenously distributed across the transect as TFe (Table 2, Fig. 2C). Finally, the concentration of $\mathrm{Al}_{\text {amorp }}$ was significantly lower in MT $\left(3122 \pm 1069 \mathrm{mg} \cdot \mathrm{Kg}^{-1}\right)$ than in M $\left(7806 \pm 842 \mathrm{mg} \cdot \mathrm{Kg}^{-1}\right)$ (Table 2, Fig. 2C), but was homogeneously distributed at depth.

The bioavailability of micro and macronutrients was quite high in both units relative to the Mylavarapu categories (Mylavarapu et al., 2014). The concentration of $P$ was high in MT ( $>200 \mathrm{mg} \cdot \mathrm{kg}^{-1}$ ) and intermediate in $\mathrm{M}\left(38.1-69.1 \mathrm{mg} \cdot \mathrm{kg}^{-1}\right)$. The concentration of $\mathrm{K}$ was intermediate $\left(82.2 \mathrm{mg} \cdot \mathrm{kg}^{-1}\right)$ along the transect, except in $\mathrm{MT}_{\mathrm{S}}$, in which it was high ( $>211 \mathrm{mg} \cdot \mathrm{kg}^{-1}$ ). The concentrations of $\mathrm{P}$ and $\mathrm{Ca}$ were statistically significantly higher in MT than in M. There were no statistically significant differences in the concentrations of the other micro and macronutrients (Table 2).

Laboratory simulation of glacier abrasion by grinding revealed an increase in $\mathrm{Al}_{\text {oxa }}$ as well as $\mathrm{Fe}_{\text {oxa }}$ and $\mathrm{Si}_{\text {oxa }}$ in the ground samples. There was a mean increase of $44 \%$ and $19 \%$ for $\mathrm{Al}_{\text {oxa }}$ in $\mathrm{MT}$ and $\mathrm{M}$ (respectively) and a $72 \%$ and $67 \%$ for $\mathrm{Si}_{\text {oxa }}$ in MT and M (respectively) (Table 2, Fig. 2). There were no statistically significant differences in the concentrations of $\mathrm{Al}, \mathrm{Fe}$ or $\mathrm{Si}$ between the units.

\subsection{Total phosphorus and partitioning in soil}

Total P (TP) was approximately two times higher in the MT unit (from 1348 to $4799 \mathrm{mg} \cdot \mathrm{kg}^{-1}$ ) than in the $\mathrm{M}$ unit (from 1006 to $1480 \mathrm{mg} \cdot \mathrm{kg}^{-1}$ ), and the concentration of TP was significantly higher in MT than in M (Table 2). On the other hand, $\mathrm{TP}_{\text {sand }}$ showed a basal level along the transect without significant differences neither between geomorphological units nor in depth (Table 2).

Phosphorus partitioning showed two main fractions linked to the geomorphologic units. The dominant fraction in MT was P-Al/Clay (from $34 \%$ to $66 \%$; Fig. 2), whereas $\mathrm{P}-\mathrm{Ca}$ was the dominant fraction in $\mathrm{M}$ (57\%-75\%). The concentrations of adsorbed $\mathrm{P}$ were very low in both cases, representing $<0.2 \%$ of the total $\mathrm{P}$. The concentration of $\mathrm{P}$ associated with Fe and HA was higher in MT (from $10.1 \%$ to $18.6 \%$ and from $3.1 \%$ to $6.7 \%$, respectively) than in $\mathrm{M}$ (from $1.3 \%$ to $8 \%$ and from $1.2 \%$ to $3.4 \%$, respectively). Finally, although the recalcitrant $\mathrm{P}$ fraction represents $7.4 \%$ in MT and $10.6 \%$ in M, the amount of residual P was higher in MT (Table 2, Fig. 4). The $\mathrm{P}$ partitioning of phosphorus can be summarized as follow:

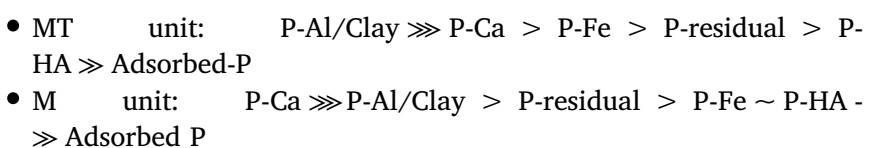

\subsection{Mineralogy}

The clay mineralogy composition was clearly different in the two units considered (Fig. 5). MT soils contained a higher proportion of phosphate minerals such as struvite $(0.590 \mathrm{~nm}, 0.560 \mathrm{~nm}$ and $0.269 \mathrm{~nm})$, leucophosphite $(0.670 \mathrm{~nm}, 0.550 \mathrm{~nm}, 0.470 \mathrm{~nm})$, minyulite $(0.690 \mathrm{~nm})$ taranakite $(1.54 \mathrm{~nm}, 0.760 \mathrm{~nm})$ and hydroxylapatite $(0.281 \mathrm{~nm}, 0.277 \mathrm{~nm}, 0.271 \mathrm{~nm})$. On the other hand, the $M$ soils contained a higher abundance of secondary minerals such as vermiculite, chlorite $(1.42 \mathrm{~nm})$, kaolinite $(0.71 \mathrm{~nm})$ and talc $(0.94 \mathrm{~nm})$, as well as interstratified minerals such as chlorite/vermiculite $(2.91 \mathrm{~nm})$ (see Fig. 6 for more detail). However, there were no phosphate minerals in the clay fraction of the M soil (Fig.5).

Sand and silt fractions were dominated by primary minerals in both units (Fig. 5), with plagioclase $(0.688 \mathrm{~nm}, 0.644 \mathrm{~nm}, 0.403-0.405 \mathrm{~nm}$, $0.374 \mathrm{~nm}, \quad 0.388 \mathrm{~nm}, \quad 0,366 \mathrm{~nm}, \quad 0.334 \mathrm{~nm}, \quad 0.327 \mathrm{~nm}$ and $0.319-0.320 \mathrm{~nm})$ and quartz $(0.427-0.425 \mathrm{~nm})$ being particularly important.

The silt fraction contained a combination of minerals found in MT and $\mathrm{M}$ clays. Some phosphate minerals and secondary minerals were observed such as those found in M clays (Fig. 5). Iron oxides were also identified in silt fraction of the two units. Magnetite $(0.252 \mathrm{~nm})$ and maghemite $(0.252)$ were identified in MT, and goethite was detected in Mt. $(0.417 \mathrm{~nm})$.

Finally, XRD analysis of sand revealed very similar composition in the two units (Fig. 5) with primary minerals dominating. No crystalline phosphate minerals were found in this fraction in either unit.

\subsection{PCA of key variables}

The PCA clearly revealed two principal components $\left(\mathrm{PC}_{\mathrm{s}}\right)$ with eigenvalues $>1$ (Kaiser index). These $\mathrm{PC}_{\mathrm{s}}$ explained $89 \%$ of the total variance (Fig. 7). PC1 accounted for a large proportion of the variance (73\%) and was dominated by the high positive loadings (0.989-0.930) of $\mathrm{Al}_{\text {pyro, }}$, TP and $\mathrm{Fe}_{\text {pyro, }}$, the moderate positive loading of $\mathrm{P}_{\mathrm{Meh}}$ and the medium negative loading of $\mathrm{pH}_{\mathrm{w}}$. The variance of PC2 was mainly explained by $\mathrm{Al}_{\text {amorp }}, \mathrm{pH}_{\mathrm{w}}, \mathrm{pH}_{\mathrm{NaF}}$ and silt + clay fraction, which showed positive loadings between 1.072 and 0.646 . All variables had communalities higher than 0.75 , and variations in the transect were thus dominated by processes involving these factors. The plot of rotated variables against factor score values (FSV) of sample points (Fig. 7) shows the extent to which the samples were influenced by the components or groups of variables. Two groups of samples were clearly differentiated (see ellipses in Fig. 7). Each group corresponds to samples from each geomorphological unit, except samples EP1-1 and EP2-1, which correspond to the MT unit (Fig. 7). The group on the right is 

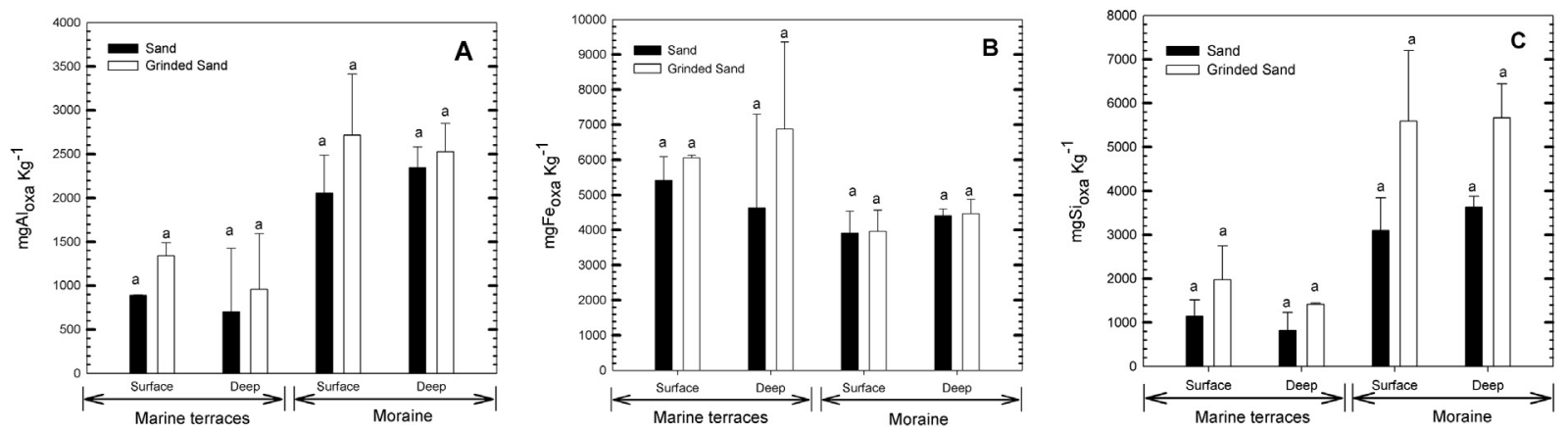

Fig. 3. Concentrations of $\mathrm{Si}, \mathrm{Al}$ and $\mathrm{Fe}$ extracted in ammonium oxalate after simulation of glacial abrasion by grinding process. $\mathrm{N}=2$.

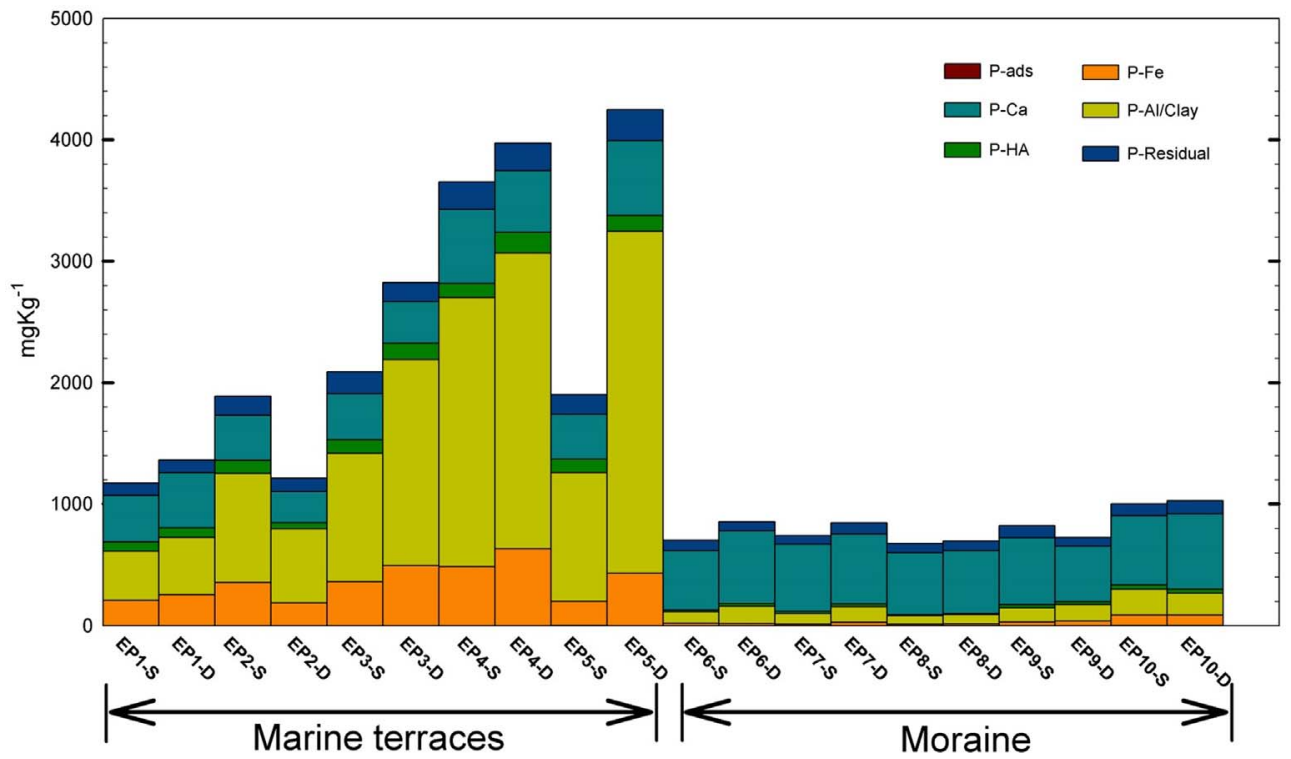

Fig. 4. Phosphorus partitioning. Deep samples are indicated by "D" and surface samples by "S".

mainly influenced by PC1, while the upper group is mainly dominated by PC2 and to a lesser extent by PC1. These results indicate that the soil properties in each unit are strongly influenced by different factors.

\section{Discussion}

Some authors have suggested that temperature and humidity play essential role in various soil-forming processes in cold climate and humid environments (e.g. Campbell and Claridge, 1982; Matsuoka et al., 1990), as they strongly influence freeze-thaw cycles (Henry, 2007), frost shattering (Lautridou and Ozouf, 1982) and glacial advances or retreats (Cook et al., 2005). These factors also affect edaphic processes, which are spatially very variable (Tanner et al., 2013), as well as geomorphological activity (Oliva and Ruiz-Fernández, 2017). Other authors have noted the great differences in soil properties that can be generated by the presence of seabirds and seals, which disturb the soil by trampling and by input of organic compounds in their droppings, which can accumulate to form guano and favour establishment of vegetation (Brimble et al., 2009; Otero et al., 2015b; Ugolini, 1972). The findings of the present study revealed two clearly different geochemical environments (Fig. 7). These environments are closely related to the geomorphological units studied. One of them includes the marine terrace samples and the variables affected by biota activity. In this respect, biota seems to be the main soil forming factor in marine terraces, responsible for the enrichment in nutrients and labile forms of metals and P in MT soils. The moraine environment is defined by those variables associated with geomorphological activity (Fig. 7). In the moraine, geomorphological activity seems to be the most important soil forming factor, yielding fine particles and high $\mathrm{pH}$.

\subsection{Biota action}

Biota is an important soil-forming factor, as already described in several other Antarctica environments (Lee et al., 2004; Otero et al., 2013; Ziółek and Melke, 2014). Seabird colonies established along the coast physically and chemically modify the soil properties via the input of faecal matter and also via trampling (Bockheim, 2015; Cannone et al., 2008). In the present study, the seabird and seal colonies present on the marine terraces are the main source of organic matter, as reflected in the high values of TOC in MT ( $1 \%)$ relative to values in M $(\sim 0.17 \%)$, in which organic matter may be accumulated by permafrost table and to favour the humification process. The biota is also responsible for the higher concentration of TN in MT, which is well correlated with the values of TOC. This element is more abundant in the first $10 \mathrm{~cm}$ of soil due to the release of faecal matter (Simas et al., 2007). Although faecal matter is initially alkaline, deposition by seabirds and seals has promoted soil acidification and leaching of base cations and enhanced microbial degradation of organic matter; this is common in cold environments where higher temperatures prevail, as in Maritime Antarctica (Bockheim, 2015).

The high concentrations of TP and $\mathrm{P}_{\mathrm{Meh}}$ in MT, respectively 2 and 10 times higher than in $\mathrm{M}$ (Table 2), should also be interpreted as a direct effect of the seabird and elephant seal colonies on the soils. The droppings that these animals produce are rich in phosphorus com- 


\section{Clay fraction}
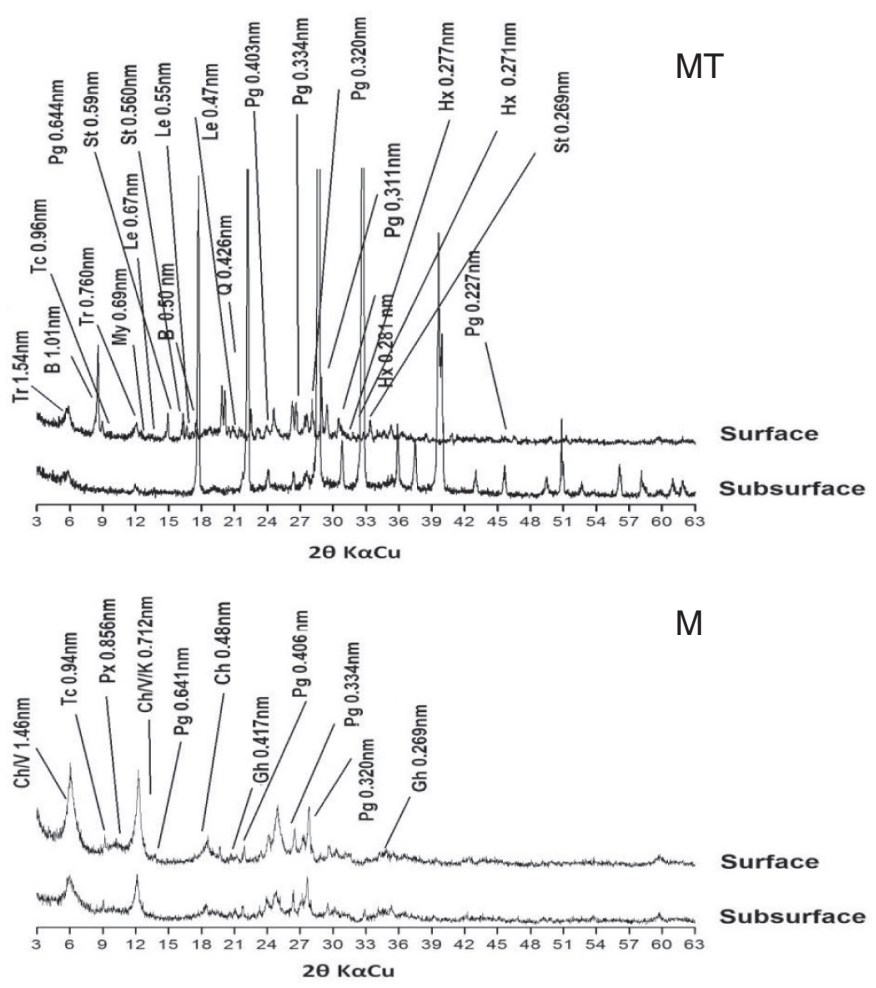

Sand fraction
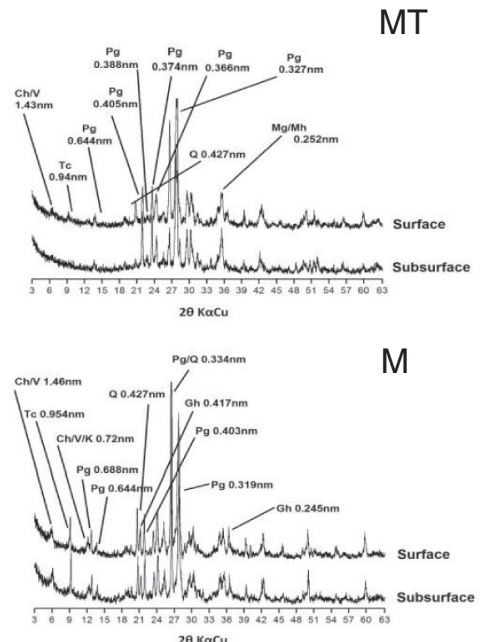

Silt fraction
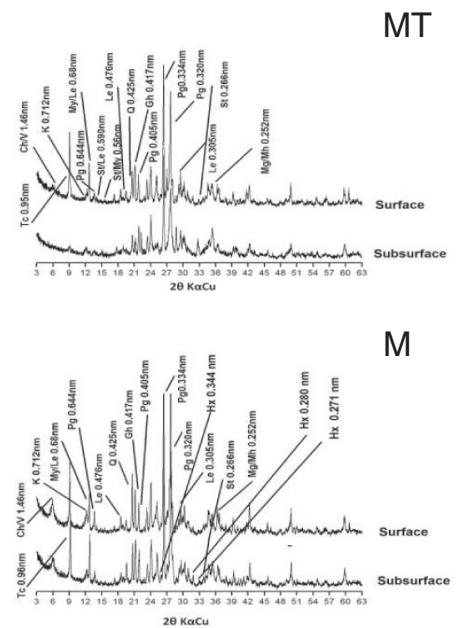

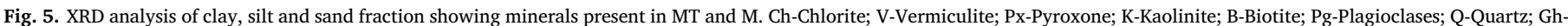
Goethite; Hx-Hydroxylapatite; Tr-Taranakite; St-Struvite; Le-Leucophosphite and My-Minyulite.

pounds and thus substantially increase the natural fertility of the soil in the breeding areas (Anderson and Polis, 1999; Ligeza and Smal, 2003; Otero et al., 2015b; Ziółek and Melke, 2014).

The results of the mineralogical and $\delta^{15} \mathrm{~N}$ analyses are consistent with this interpretation. The MT mineralogy shows a high diversity of phosphate minerals, which are typically associated with faecal matter (Pereira et al., 2013b; Simas et al., 2007). The high concentration of $P$ favours phosphatization processes (Tatur and Barczuk, 1985). These processes imply the formation of secondary minerals such as tarana-

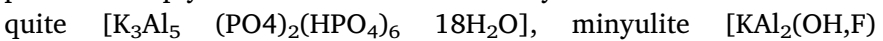
$\left.\left(\mathrm{PO}_{4}\right)_{2} \cdot 4 \mathrm{H}_{2} \mathrm{O}\right]$, leucophosphite $\left.\left[\mathrm{KFe}_{2}\left(\mathrm{PO}_{4}\right)_{2} \mathrm{OH}\right) 2 \mathrm{H}_{2} \mathrm{O}\right]$, struvite $\left[\left(\mathrm{NH}_{4}\right) \mathrm{Mg}\left(\mathrm{PO}_{4}\right) 6\left(\mathrm{H}_{2} \mathrm{O}\right)\right]$ and hydroxylapatite $\left[\mathrm{Ca}_{5}\left(\mathrm{PO}_{4}\right) \mathrm{OH}\right]$ (Pereira et al., 2013a; Tatur and Myrcha, 1984), as clearly indicated by the composition of the MT clay fraction. However, hydroxylapatite may be derived from hydrated mass of decomposing faecal matter in earthy aggregates of calcium phosphate or from geological material. This occurs in the M unit (silt fraction of Fig. 5), where there is no biota, probably due to recent deglaciation, higher slope and active cryoturbation processes. Thus, hydroxilapatite is not exclusively formed as a result of phosphatization processes (Tatur and Myrcha, 1984).

The P partitioning also shows the importance of phosphatization processes in the soil, reflected in the very different distribution of $\mathrm{P}$ relative to that in seabird faecal matter (Otero et al., 2015b). The amount of $\mathrm{P}$ associated with reducible $\mathrm{Fe}$ and $\mathrm{Mn}$ oxyhydroxides was 

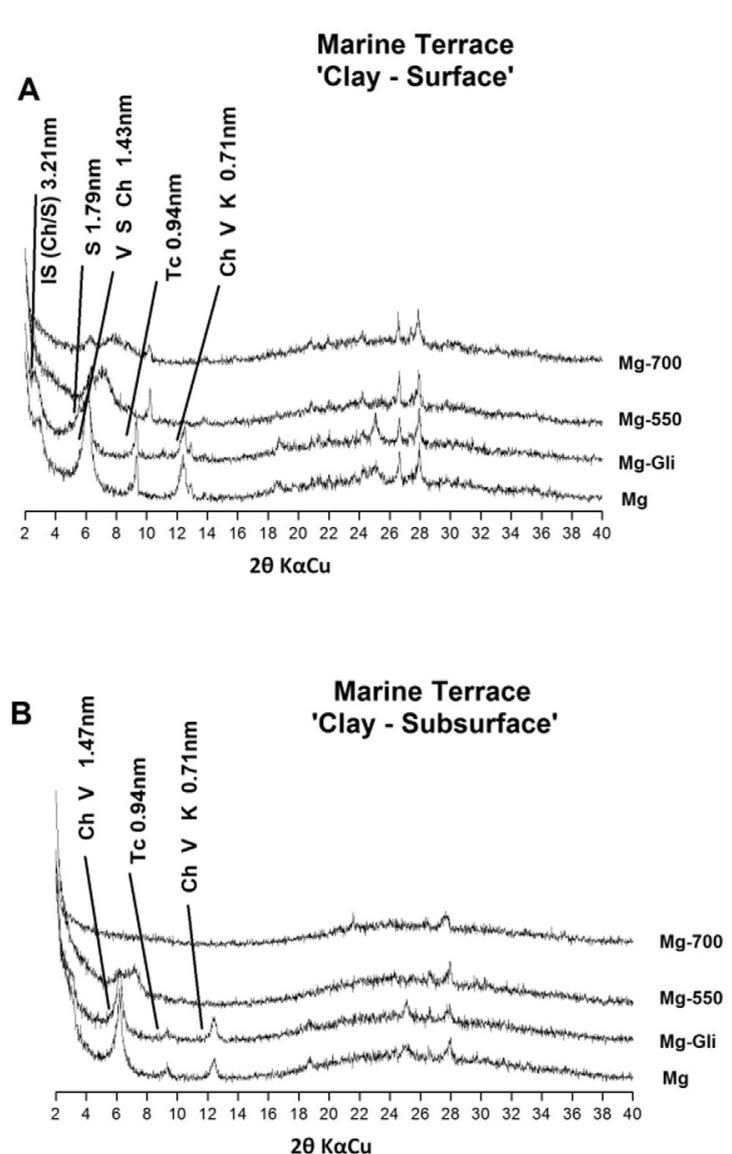
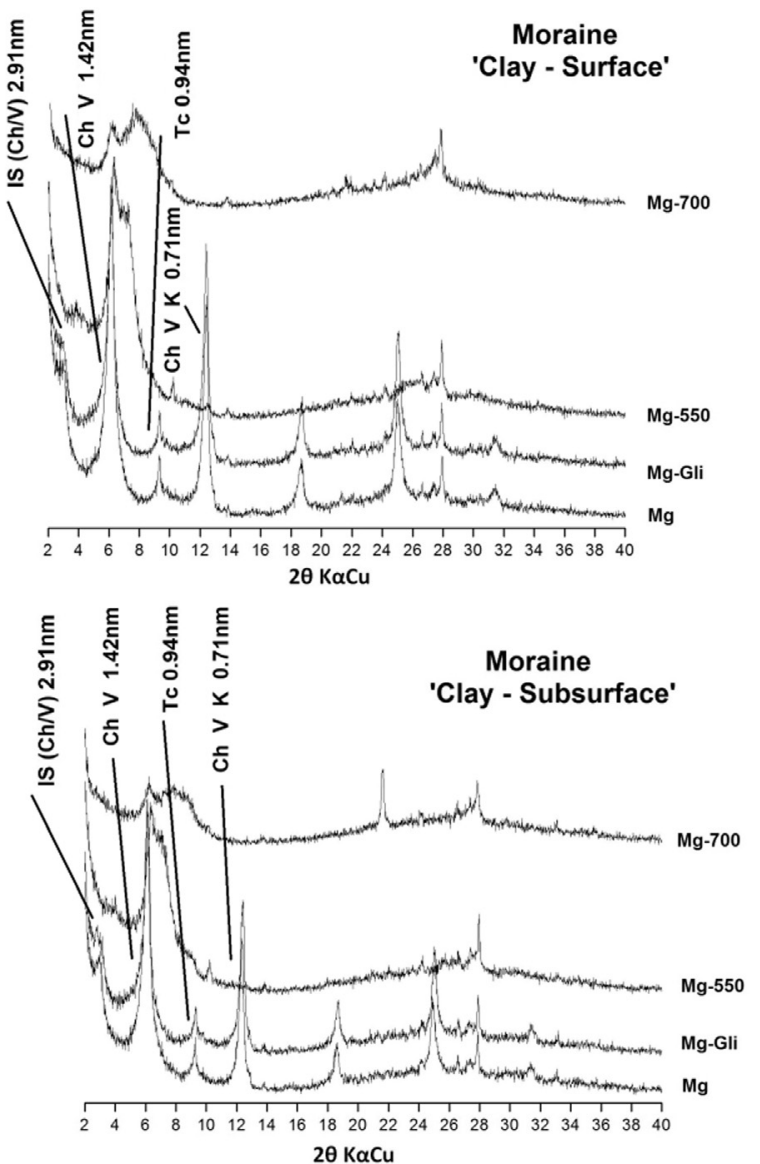

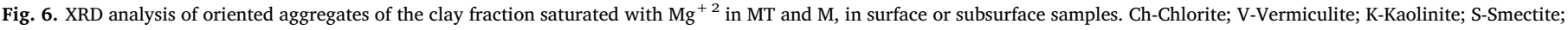
Tc-Talc and interstratified (IS) minerals as $\mathrm{Ch} / \mathrm{V}$ and $\mathrm{Ch} / \mathrm{S}$.

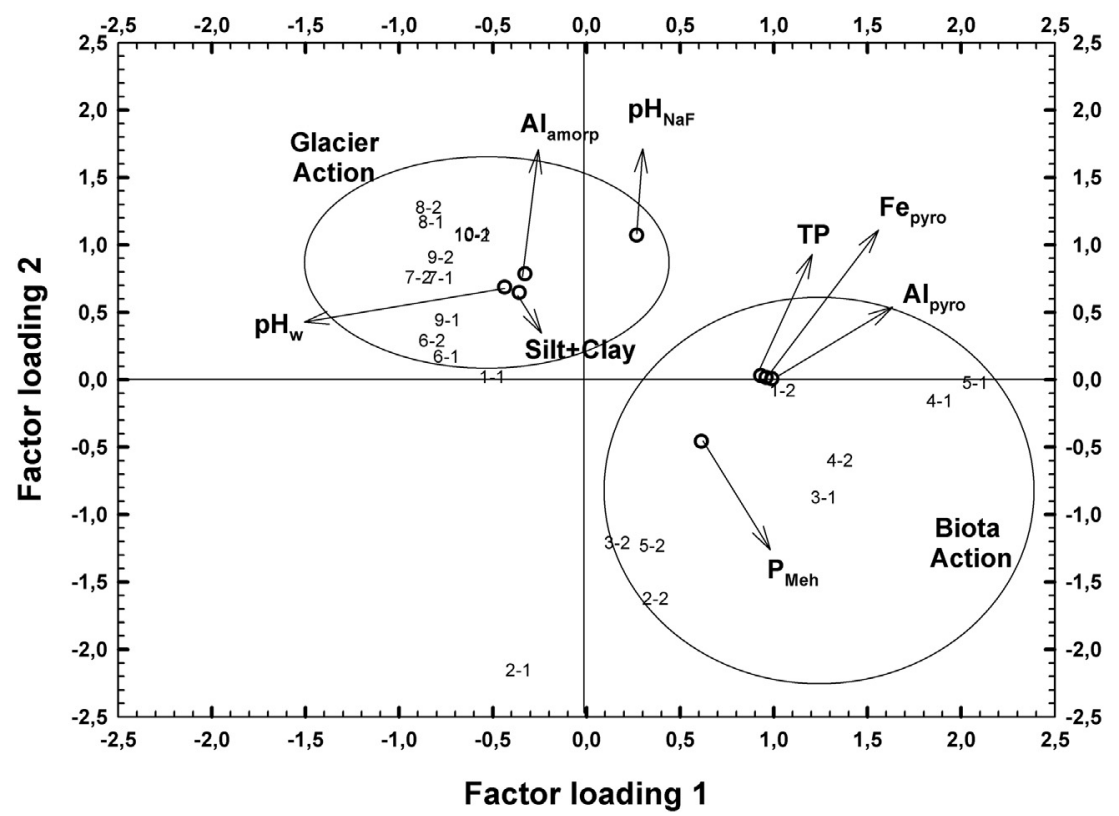

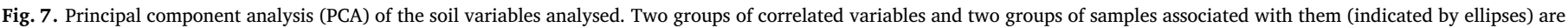
shown.Note: Sampling points were labelled without the prefix "EP" (Elephant Point) to make them easier to read.

much higher in MT due to the low pH (Sims and Pierzynski, 2005; Wild, 1993). The $\mathrm{P}$ fraction associated with $\mathrm{Al}$ and clays (P-Al/Clay) is much more abundant in MT than in M. This is mainly because this fraction is one of the common forms in seabird faecal matter. However, this great difference between geomorphological units is presumably also due to the background level, which was higher than found in previous studies (Otero et al., 2015b; Ziółek and Melke, 2014). The P-HA also seems to be strongly related to the effect of seabirds on soil due to the higher concentration of MT (Otero et al., 2015b). The concentration of the $\mathrm{P}-\mathrm{Ca}$ fraction is similar in both areas. This is a dominant fraction in 
seabird excrements (Otero et al., 2015b; Ziółek and Melke, 2014), which could therefore explain the high concentration in MT unit. However, the high concentration of this fraction in $\mathrm{M}$ may be a consequence of the weathering of parent material and allochthonous rocks such as granodiorite, which contain apatite. Thus, allochthonous material transported from Antarctic Peninsula by icebergs (Oliva and Ruiz-Fernández, 2017) may account for the presence of struvite, leucophosphite and hydroxylapatite in the silt fraction of $\mathrm{M}$ and may also explain the basal level of $\mathrm{P}_{\text {sand }}$ (Table 2).

The isotopic composition of $\mathrm{N}$ in the MT unit $\left(\delta^{15} \mathrm{~N}\right.$ : from 13 to $17.7 \%$ ) was much higher than in $\mathrm{M}\left(\delta^{15} \mathrm{~N}\right.$ : from 3 to $7.8 \%$ ), indicating different sources. The values for $\mathrm{M}$ are similar to those for particulate organic material (POM) $(6.8 \pm 0.3 \%)$ and algae $(5.1 \pm 0.3 \%$ ) (Yuan et al., 2010) which can grow on the moraine. On the other hand, the high values of $\delta^{15} \mathrm{~N}$ in MT soils were similar to those obtained in soils (Mizutani et al., 1991), sediments (Liu et al., 2006; Nie et al., 2014; Yuan et al., 2010) and excrements derived from seabird and mammalian colonies ( $\delta^{15} \mathrm{~N}=$ from 11.3 to $16.2 \%$ ) (Liu et al., 2006).

These findings reinforce the important influence of seabird and seal colonies (biota) have on soil formation and consequently on soil properties and composition. The presence of biota leads to input of organic matter, which changes the geochemical properties and contributes to the development of the A horizon. The biota is also responsible for other soil-forming processes such as podsolization. This process is highly incipient in Maritime Antarctica (Bockheim and Ugolini, 1990), but can be observed in different dark and grey lines in some horizons of marine terraces. This is favoured in the summer season when the ice melts on well-drained acid soil (Bockheim and Ugolini, 1990). The process is caused by the chemical migration of aluminium, iron or organic matter in depth as reflected in the values of $\mathrm{Al}$ and Fe extracted by pyrophosphate (Table 2). The decomposition of faecal matter also promotes acidolysis and enhances chemical weathering and plant development.

In addition to causing eutrophication of soils, waters and sediments, seabirds are also efficient vectors of seed dispersion (Calviño-Cancela, 2002), thus favouring biodiversity of the vegetation in this extreme environment (Myrcha and Tatur, 1991). In this respect, in the current scenario of climate change, plant colonization in these distant coastal areas may be accelerated by the action of seabirds, with the associated consequences, such as the increased discharge of phosphorus to the ocean, lakes or rivers (Hawkings et al., 2016).

\subsection{Geomorphic action}

Despite the length of time that has passed since the retreat of the glacier, the moraine sediments show evidence of intense glacial abrasion. Glaciers exert high pressure on rocks and minerals. They grind and break the substrate, thus forming finer particles $(<32 \mu \mathrm{m})$ (Haldorsen, 1981; Jari, 1995; Keller and Reesman, 1963b). Physical weathering explains the presence of primary minerals in clay fraction of moraine sediments and also the high $\mathrm{pH}$. Glacial abrasion leads to changes in mineral structure (Fig. 5, Table 2), increasing the $\mathrm{pH}$ to values close to those obtained in the abrasion $\mathrm{pH}$ as a consequence of the release of $\mathrm{OH}$ groups of the crystalline structure (Gonzalez Garcia et al., 1991; Miller and Oulton, 1970; Takahashi, 1957). This loss generates amorphous minerals, e.g. of Al (Campbell and Caridge, 1987; Jari, 1995; Keller and Reesman, 1963a, 1963b; Ramesh and d'Anglejan, 1997) in the moraine. The results of the simulated glacier abrasion by grinding are consistent with this idea (Fig. 3). Unconsolidated sediments of the $\mathrm{M}$ unit are affected by very intense post-glacial activity of periglacial processes, particularly during the paraglacial stage (Oliva and Ruiz-Fernández, 2017). The effectiveness of cryogenic processes in the Maritime Antarctica is enhanced during the summer season when freeze-thaw cycles are frequent and moisture is abundant. This favours physical weathering processes, namely the frost-induced shattering of the boulders left by the glacier (Woronko and Pisarska-Jamrozy, 2016).
This action is more intense when the grain surface is encrusted by amorphous phases (Woronko and Hoch, 2011). These processes may also explain the finer particles found in M than in MT (Campbell and Caridge, 1987), as well as the $\mathrm{pH}$ values close to $\mathrm{pH}$ abrasion and the presence of inherited primary minerals resulted from physical weathering. After the actions of the above-mentioned processes, strong winds and retreating and advancing movements of glaciers are the main causes of erosion as they move the soil material to new sites, thus contributing to the pedogenic processes as losses and additions (e.g. alluvial fans).

The absence of these properties in the MT is related to their nonglacial origin and to the horizontal surface of the terrain, which facilitates development of the vegetation cover, reducing periglacial slope processes and encouraging geomorphologic stability. The vegetation cover also limits the effects of frost on the ground and the effects of wind abrasion, which can strongly influence the geological material (Matsuoka et al., 1996) and may be another factor explaining the differences between two geomorphological units. However, more detailed studies are required to clarify the role of this weathering agent in soil formation.

Finally, the lack of any differences in the variables at the depths of soil considered can be explained by mixing of materials and homogenization of the soil profile due to cryogenic processes such as cryoturbation (Ugolini et al., 2006).

\section{Conclusions}

The study findings showed clear differences in soil properties and composition of marine terraces and moraine as a consequence of the biotic and geomorphic actions.

Biotic activity, driven mainly by seabird and seal colonies, seems to be the most important soil forming factor in the marine terraces. The faecal matter adds different types of organic matter, favours chemical weathering and contributes to eutrophication of the environment due to the high concentration of nutrients. Phosphatization may thus be considered the most representative soil forming process in this unit, as a consequence of the high concentration of $\mathrm{P}$ in faecal matter. The formation of new $\mathrm{P}$ minerals favours accumulation of $\mathrm{P}$ (and to a lesser extent $\mathrm{N}$ ) in soils, although the increased erosion of the Antarctic coast due to ice melting may lead to eutrophication in nearby seas and lagoons.

In the moraine unit, soil formation is mainly driven by glacial abrasion. Rock abrasion destroys the crystalline structure of primary minerals, releasing $\mathrm{Fe}$ and $\mathrm{Al}$; this leads to neoformation of secondary minerals with low degree of crystallinity and with high reactivity. This process is also driven by the alkaline reaction in moraine soils. Additionally, freeze-thaw cycles and frost shattering also contribute to the disintegration of rocks (e.g. sharp-edged clasts) and consequently generate fine particles such as silts and clays.

Finally, future studies should aim to clarify the role of geomorphological and physical processes in the development of soils in the Maritime Antarctica. Information about how glacial abrasion by grinding influences soil development is scarce. This research topic is of potential interest for advancing knowledge of soil texture, mineralogy and $\mathrm{pH}$ in ice-free environments. Study of the consequences of the weathering, such as the losses of Fe to the ocean is also of interest, as Fe is a limiting nutrient for primary productivity.

\section{Acknowledgements}

The authors are grateful to Maria Santiso, David Romero and Francisco Casás for help with the laboratory analysis and to Christine Helen Francis for help with revising earlier drafts of the manuscript. X.L.O. is grateful for financial support from the Proyecto PROMETEO (SENESCYT Ecuador) and Marc Oliva is grateful for funding from the project HOLOANTAR (Holocene environmental change in Maritime 
Antarctic. Interactions between permafrost and lacustrine environment) and the Portuguese Polar Program (PROPOLAR), both from Portuguese Science Foundation. We also acknowledge the logistic support of the Brazilian and Chilean Antarctic Programs during fieldwork. Finally, A.G.G. is grateful to MINECO and FSE for the FPI pre-doctoral contract obtained through the "Programa Estatal de Promoción del Talento y su Empleabilidad en I + D + I".

\section{References}

Allen, C.E., Darmody, R.G., Thorn, C.E., Dixon, J.C., Schlyter, P., 2001. Clay mineralogy, chemical weathering and landscape evolution in Arctic - Alpine Sweden. Geoderma 99, 277-294. http://dx.doi.org/10.1016/S0016-7061(00)00075-6.

Anderson, W.B., Polis, G.A., 1999. Nutrient fluxes from water to land: seabirds affect plant nutrient status on gulf of California islands. Oecologia 118, 324-332. http://dx. doi.org/10.1007/s004420050733.

Anderson, S.P., Drever, J.I., Humphrey, N.F., 1997. Chemical weathering in glacial environments. Geology 25, 399-402. http://dx.doi.org/10.1130/0091-7613(1997) 025.

Bañón, M., Justel, A., Velázquez, D., Quesada, A., 2013. Regional weather survey on Byers Peninsula, Livingston Island, South Shetland Islands, Antarctica. Antarct. Sci. 25, 146-156. http://dx.doi.org/10.1017/S0954102012001046.

Bascomb, C.L., 1968. Distribution of pyrophosphate-extractable iron and organic carbon in soils of various groups. Eur. J. Soil Sci. 19, 251-268. http://dx.doi.org/10.1111/j. 1365-2389.1968.tb01538.x.

Beyer, L., Pingpank, K., Wriedt, G., Bölter, M., 2000. Soil formation in coastal continental Antarctica (Wilkes land). Geoderma 95, 283-304.

Bhatia, M.P., Kujawinski, E.B., Das, S.B., Breier, C.F., Henderson, P.B., Charette, M.a., 2013. Greenland meltwater as a significant and potentially bioavailable source of iron to the ocean. Nat. Geosci. 6, 274-278. http://dx.doi.org/10.1038/ngeo1746.

Blakemore, L.C., 1983. Acid Oxalate-Extractable Iron, Aluminium and Silicon, ICOMAND, Circular Letter

Bockheim, J.G., 2015. The Soils of Antarctica. Springer, New York. http://dx.doi.org/10. 1007/978-3-319-05497-1.

Bockheim, J.G., Ugolini, F.C., 1990. A review of pedogenic zonation in well-drained soils of the southern circumpolar region. Quat. Res. 34, 47-66.

Bockheim, J., Vieira, G., Ramos, M., López-Martínez, J., Serrano, E., Guglielmin, M. Wilhelm, K., Nieuwendam, A., 2013. Climate warming and permafrost dynamics in the Antarctic Peninsula region. Glob. Planet. Chang. 100, 215-223. http://dx.doi. org/10.1016/j.gloplacha.2012.10.018.

Brimble, S.K., Foster, K.L., Mallory, M.L., MacDonald, R.W., Smol, J.P., Blais, J.M., 2009. High arctic ponds receiving biotransported nutrients from a nearby seabird colony are also subject to potentially toxic loadings of arsenic, cadmium, and zinc. Environ. Toxicol. Chem. 28, 2426-2433. http://dx.doi.org/10.1897/09-235.1.

Calviño-Cancela, M., 2002. Spatial patterns of seed dispersal and seedling recruitment in Corema album (Empetraceae): the importance of unspecialized dispersers for regeneration. J. Ecol. 90, 775-784. http://dx.doi.org/10.1046/j.1365-2745.2002. 00711.x.

Campbell, I.B., Caridge, G.G.C., 1987. Antarctica: Soils, Weathering Processes and Environment. Elsevier Science Publishers B.V, Amsterdam.

Campbell, I.B., Claridge, G.G.C., 1982. The influence of moisture on the development of soils of the cold deserts of Antarctica. Geoderma 28, 221-238. http://dx.doi.org/10. 1016/0016-7061(82)90004-0.

Cannone, N., Wagner, D., Hubberten, H.W.W., Guglielmin, M., 2008. Biotic and abiotic factors influencing soil properties across a latitudinal gradient in Victoria land, Antarctica. Geoderma 144, 50-65. http://dx.doi.org/10.1016/j.geoderma.2007.10. 008.

Cook, A.J., Fox, A.J., Vaughan, D.G., Ferrigno, J.G., 2005. Retreating glacier fronts on the Antarctic Peninsula over the past half-century. Science 308, 541-544. http://dx.doi. org/10.1126/science.1104235.

Cowton, T., Nienow, P., Bartholomew, I., Sole, A., Mair, D., 2012. Rapid erosion beneath the Greenland ice sheet. Geology 40, 343-346. http://dx.doi.org/10.1130/G32687.1.

Dixon, J.C., 2013. Chemical weathering in cold climates. In: Shroder, J., Pope, G.A. (Eds.), Weathering and Soils Geomorphology. Elsevier Ltd., San Diego, pp. 245-257. http://dx.doi.org/10.1016/B978-0-12-374739-6.00063-4.

Ferrari, G.A., Magaldi, D., 1983. Degree of soil weathering as determined by abrasion pH: applications in soil study and in paleopedology., in: Bullock, P., D'Hoore, J., Dudal, R., Frankart, R., Girard, M., Hanotiaux, G., Hayes, M.H.B., Herbillon, A., Schwertmann, U., Sys, C., Van Ruymbeke, M., Chief editor: Verheye, W. (Eds.), Pedologie. Société Belge de Pédologie, Gent, pp. 93-104.

Fretwell, P.T., Hodgson, D.A., Watcham, E.P., Bentley, M.J., Roberts, S.J., 2010. Holocene isostatic uplift of the South Shetland Islands, Antarctic Peninsula, modelled from raised beaches. Quat. Sci. Rev. 29, 1880-1893. http://dx.doi.org/10.1016/j. quascirev.2010.04.006.

Gee, G.W., Bauder, J.W., 1986. Particle-size analysis. In: Klute, A. (Ed.), Methods of Soil Analysis. American Society of Agronomy and Soil Science Society of America, Madison, pp. 383-412.

Gengnian, L.I.U., Yixin, C., Yue, Z., Hairong, F.U., 2009. Mineral deformation and subglacial processes on ice-bedrock interface of Hailuogou glacier. Chin. Sci. Bull. 54, 3318-3325. http://dx.doi.org/10.1007/s11434-009-0289-x.

Gonzalez Garcia, F., Ruiz Abrio, M.T., Gonzalez Rodriguez, M., 1991. Effects of dry grinding on two kaolins of different degrees of crystallinity. Clay Miner. 26, 549-565. http://dx.doi.org/10.1180/claymin.1991.026.4.09.
Haldorsen, S., 1981. Grain-size distribution of subglacial till and its relation to glacial crushing and abrasion. Boreas 10, 91-105. http://dx.doi.org/10.1111/j.1502-3885. 1981.tb00472.x.

Hall, K., 1997. Rock temperatures and implications for cold region weathering I: new data from Viking Valley, Alexander Island, Antarctica. Permafr. Periglac. Process. 8, 69-90.

Hall, K., 2004. Evidences for freeze-thaw events and their implications for rock weathering in northern Canada. Earth Surf. Process. Landf. 29, 43-57. http://dx.doi. org/10.1002/esp.1012.

Hall, K., Thorn, C.E., Matsuoka, N., Prick, A., 2002. Weathering in cold regions: some thoughts and perspectives. Prog. Phys. Geogr. 26, 577-603. http://dx.doi.org/10. 1191/0309133302pp353ra.

Hawkings, J.R., Wadham, J.L., Tranter, M., Lawson, E., Sole, A., Cowton, T., Tedstone, A.J., Bartholomew, I., Nienow, P., Chandler, D., Telling, J., 2015. The effect of warming climate on nutrient and solute export from the Greenland Ice Sheet. Geochem. Perspect. Lett. 94-104. http://dx.doi.org/10.7185/geochemlet.1510.

Hawkings, J., Wadham, J., Tranter, M., Telling, J., Bagshaw, E., 2016. The Greenland Ice Sheet as a hot spot of phosphorus weathering and export in the Arctic. Glob. Biogeochem. Cycles 30, 1-20. http://dx.doi.org/10.1002/2015GB005237.

Henry, H.A.L., 2007. Soil freeze-thaw cycle experiments: trends, methodological weaknesses and suggested improvements. Soil Biol. Biochem. 39, 977-986. http://dx. doi.org/10.1016/j.soilbio.2006.11.017.

Hodson, A., Mumford, P., Lister, D., 2004. Suspended sediment and phosphorus in proglacial rivers: bioavailability and potential impacts upon the P status of icemarginal receiving waters. Hydrol. Process. 18, 2409-2422. http://dx.doi.org/10. 1002/hyp.1471.

Jackson, M.L., 1979. Soil Chemical Analysis:Advanced Course, second ed. (Madison, Wisconsin).

Jari, M., 1995. Effects of grinding and chemical factors on the generation and composition of the till fine fraction: an experimental study. J. Geochem. Explor. 54, 49-62. http://dx.doi.org/10.1016/0375-6742(95)00008-D.

Jolliffe, I.T., 2002. Principal Component Analysis, second ed. Springer Verlag, New York. http://dx.doi.org/10.1198/jasa.2008.s230.

Keller, W.D., Reesman, A.L., 1963a. Glacial milks and their laboratory-simulated counterparts. Geol. Soc. Am. Bull. 74, 61-76.

Keller, W.D., Reesman, A.L., 1963b. Dissolved products of artificially pulverized silicate minerals and rocks: part II. J. Sediment. Petrol. 33, 426-437.

Lautridou, J., Ozouf, J., 1982. Experimental frost shattering: 15 years of research at the Centre de Geomorphologie du CNRS. Prog. Phys. Geogr. 6, 215-232.

Lee, Y. Il, Lim, H.S., Yoon, H. Il, 2004. Geochemistry of soils of King George Island, South Shetland Islands, West Antarctica: implications for pedogenesis in cold polar regions. Geochim. Cosmochim. Acta 68, 4319-4333. http://dx.doi.org/10.1016/j.gca.2004. 01.020 .

Ligeza, S., Smal, H., 2003. Accumulation of nutrients in soils affected by perennial colonies of piscivorous birds with reference to biogeochemical cycles of elements. Chemosphere 52, 595-602. http://dx.doi.org/10.1016/S0045-6535(03)00241-8.

Liu, X.D., Li, H.C., Sun, L.G., Yin, X. Bin, Zhao, S.P., Wang, Y.H., 2006. $\delta^{13} \mathrm{C}$ and $\delta^{15} \mathrm{~N}$ in the ornithogenic sediments from the Antarctic maritime as palaeoecological proxies during the past 2000 yr. Earth Planet. Sci. Lett. 243, 424-438. http://dx.doi.org/10. 1016/j.epsl.2006.01.018.

Matsuoka, N., 2001. Solifluction rates, processes and landforms: a global review. Earth Science Rev. 55, 107-134. http://dx.doi.org/10.1016/S0012-8252(01)00057-5.

Matsuoka, N., Moriwaki, K., Iwata, S., Hirakawa, K., 1990. Ground temperature regimes and their relation to periglacial processes in the Sør Rondane Mountains, East Antarctica. Proc. NIPR Symp. Antarct. Geosci. 55-66.

Matsuoka, N., Moriwaki, K., Hirakawa, K., 1996. Field experiments on physical weathering and wind erosion in an Antarctica cold desert. Earth Surf. Process. Landf. 21, 687-699.

Mehlich, A., 1984. Mehlich 3 soil test extractant: a modification of Mehlich 2 extractant. Commun. Soil Sci. Plant Anal. 15, 1409-1416. http://dx.doi.org/10.1080/ 00103628409367568.

Mehra, O., Jackson, M., 1960. Iron oxide removal from soils and clays by a dithionitecitrate system buffered with sodium bicarbonate. In: 7th National Conference on Clays and Clay Minerals, pp. 317-327.

Miller, J.G., Oulton, T.D., 1970. Prototropy in kaolinite during percussive grinding. Clays Clay Miner. 18, 313-323. http://dx.doi.org/10.1346/CCMN.1970.0180603.

Mizutani, H., Kabaya, Y., Moors, P.J., Speir, T.W., Lyon, G.L., 1991. Nitrogen isotope ratios identify deserted seabird colonies. Auk 108, 960-964.

Molina, C., Navarro, F.J., Calvet, J., García-Sellés, D., Lapazaran, J.J., 2007. Hurd Peninsula glaciers, Livingston Island, Antarctica, as indicators of regional warming: ice-volume changes during the period 1956-2000. Ann. Glaciol. 46, 43-49. http:// dx.doi.org/10.3189/172756407782871765.

Moura, P.A., Francelino, M.R., Schaefer, C.E.G.R., Simas, F.N.B., de Mendonça, B.A.F., 2012. Distribution and characterization of soils and landform relationships in Byers Peninsula, Livingston Island, Maritime Antarctica. Geomorphology 155-156, 45-54. http://dx.doi.org/10.1016/j.geomorph.2011.12.011.

Murphy, J., Riley, J.P., 1962. A modified single solution method for the determination of phosphate in natural waters. Anal. Chim. Acta 27, 31-36.

Mylavarapu, R., Obreza, T., Morgan, K., Hochmuth, G., Nair, V., Wright, A., 2014. Extraction of soil nutrients using Mehlich-3 reagent for acid-mineral soils of Florida Univ. Florida. Inst. Food Agric. Sci. 7. https://edis.ifas.ufl.edu/pdffiles/SS/SS62000. pdf.

Myrcha, A., Tatur, A., 1991. Ecological role of the current and abandoned penguin rookeries in the land environment of the Maritime Antarctic. Polish Polar Res. 12, $3-24$.

Navarro, F.J., Jonsell, U.Y., Corcuera, M.I., Martín-Español, A., 2013. Decelerated mass 
loss of Hurd and Johnsons glaciers, Livingston Island, Antarctic Peninsula. J. Glaciol. 59, 115-128. http://dx.doi.org/10.3189/2013JoG12J144.

Nie, Y., Liu, X., Wen, T., Sun, L., Emslie, S.D., 2014. Environmental implication of nitrogen isotopic composition in ornithogenic sediments from the Ross Sea region, East Antarctica: $\Delta 15 \mathrm{~N}$ as a new proxy for avian influence. Chem. Geol. 363, 91-100. http://dx.doi.org/10.1016/j.chemgeo.2013.10.031.

Oliva, M., Ruiz-Fernández, J., 2015. Coupling patterns between para-glacial and permafrost degradation responses in Antarctica. Earth Surf. Process. Landf. 40, 1227-1238. http://dx.doi.org/10.1002/esp.3716.

Oliva, M., Ruiz-Fernández, J., 2017. Geomorphological processes and frozen ground conditions in Elephant Point (Livingston Island, South Shetland Islands, Antarctica). Geomorphology 12. http://dx.doi.org/10.1016/j.geomorph.2016.01.020.

Otero, X.L., Fernández, S., de Pablo Hernandez, M.A., Nizoli, E.C., Quesada, A., 2013. Plant communities as a key factor in biogeochemical processes involving micronutrients (Fe, Mn, Co, and $\mathrm{Cu}$ ) in Antarctic soils (Byers Peninsula, Maritime Antarctica). Geoderma 195, 145-154.

Otero, X.L., González-Guzman, A., Souza-Junior, V.S., Pérez-Alberti, A., Macías, F., 2015a. Soil processes and nutrient bioavailability in the rhizosphere of Bolax gummifera in a subantarctic environment (Martial Mountains, Ushuaia-Argentina). Catena 133, 432-440. http://dx.doi.org/10.1016/j.catena.2015.06.008.

Otero, X.L., Tejada, O., Martín-Pastor, M., De La Peña, S., Ferreira, T.O., Pérez-Alberti, A., 2015b. Phosphorus in seagull colonies and the effect on the habitats. The case of yellow-legged gulls (Larus michahellis) in the Atlantic Islands National Park (GaliciaNW Spain). Sci. Total Environ. 532, 383-397. http://dx.doi.org/10.1016/j.scitotenv. 2015.06.013.

de Pablo, M.A., Ramos, M., Molina, A., 2014. Thermal characterization of the active layer at the Limnopolar Lake CALM-S site on Byers Peninsula (Livingston Island), Antarctica. Solid Earth Discuss. 6, 679-729. http://dx.doi.org/10.5194/sed-6-6792014.

Pallant, J., 2011. SPSS Survival Manual. A Step by Step Guide to Data Analysis Using IBM SPSS, fifth ed. Open University Press. McGraw-Hill Education, Maidenhead.

Paludan, C., Jensen, H.S., 1995. Sequential extraction of phosphorus in freshwater wetland and lake sediment: significance of humic acids. Wetlands 15, 365-373. http://dx.doi.org/10.1007/BF03160891.

Paludan, C., Morris, J.T., 1999. Distribution and speciation of phosphorus along a salinity gradient in intertidal marsh sediments. Biogeochemistry 45, 197-221. http://dx.doi. org/10.1023/A:1006136621465.

Pereira, T.T.C., Schaefer, C.E.G.R., Ker, J.C., Almeida, C.C., Almeida, I.C.C., 2013a. Micromorphological and microchemical indicators of pedogenesis in Ornithogenic Cryosols (Gelisols) of Hope Bay, Antarctic Peninsula. Geoderma 193-194, 311-322. http://dx.doi.org/10.1016/j.geoderma.2012.10.023.

Pereira, T.T.C., Schaefer, C.E.G.R., Ker, J.C., Almeida, C.C., Almeida, I.C.C., Pereira, A.B., 2013b. Genesis, mineralogy and ecological significance of ornithogenic soils from a semi-desert polar landscape at Hope Bay, Antarctic Peninsula. Geoderma 209-210, 98-109.

Ramesh, R., d'Anglejan, B., 1997. Silica, iron and aluminium mobilization and transport from post-glacial sediments of the St. Lawrence Lowlands - an experimental study. J. Coast. Res. 13, 1111-1118.

Ramos, M., Hasler, A., Vieira, G., Hauck, C., Gruber, S., 2009. Drilling and installation of boreholes for permafrost thermal monitoring on Livingston Island in the Maritime Antarctic. Permafr. Periglac. Process. http://dx.doi.org/10.1002/ppp.

Rowell, D.L., 1994. Soil Science: Methods and Applications. Longman Scientific and technical, U.K.

Schaefer, C.E.G.R., Simas, F.N.B., Gilkes, R.J., Mathison, C., da Costa, L.M., Albuquerque, M.A., 2008. Micromorphology and microchemistry of selected cryosols from Maritime Antarctica. Geoderma 144, 104-115. http://dx.doi.org/10.1016/j. geoderma.2007.10.018.

Serrano, E., López-Martínez, J., Cuchí, J.A., Durán, J.J., Mink, S., Navas, A., 2008. Permafrost in the South Shetland Islands (Maritime Antarctica): spatial distribution pattern. In: Kane, D.L., Hinkel, K.M. (Eds.), 9th International Conference on Permafrost. International Permafrost Association and University of Alaska Fairbanks, vol. 2. Fairbanks, AK, pp. 1621-1625.

Simas, F.N.B., Schaefer, C.E.G.R., Melo, V.F., Albuquerque-Filho, M.R., Michel, R.F.M., Pereira, V.V., Gomes, M.R.M., da Costa, L.M., 2007. Ornithogenic cryosols from Maritime Antarctica: phosphatization as a soil forming process. Geoderma 138, 191-203. http://dx.doi.org/10.1016/j.geoderma.2006.11.011.
Simas, F.N.B., Schaefer, C.E.G.R., Albuquerque-Filho, M.R., Francelino, M.R., Filho, E.I.F., da Costa, L.M., 2008. Genesis, properties and classification of cryosols from Admiralty Bay, Maritime Antarctica. Geoderma 144, 116-122. http://dx.doi.org/10. 1016/j.geoderma.2007.10.019.

Sims, J.T., Pierzynski, G.M., Sparks, D.L., 2005. Chemistry of phosphorus in soils. In: Tabatabai, M.A. (Ed.), Chemical Processes in Soils. Soil Science Society of America Inc, pp. 151-192. (Madison, WI). http://dx.doi.org/10.2136/sssabookser8.c2.

Smellie, J.L., Pankhurst, R.J., Thomson, M.R.A., Davies, R.E.S., 1984. The geology of the South Shetland Islands. VI. Stratigraphy, geochemistry and evolution. Br. Antarct. Surv. Sci. Rep. 87, 85.

Takahashi, H., 1957. Effect of dry grinding on kaolin minerals. Sixth Natl. Conf. Clay Clay Miner. 6, 279-291.

Tanner, L.H., Walker, A.E., Nivison, M., Smith, D.L., 2013. Changes in Soil Composition and Floral Coverage on a Glacial Foreland Chronosequence in Southern Iceland 2013. pp. 191-198. http://dx.doi.org/10.4236/ojss.2013.34022.

Tatur, A., Barczuk, A., 1985. Ornithogenic phosphates on King George Island in the maritime Antarctic. Antarct. Nutr. Cycles Food Webs 163-168.

Tatur, A., Myrcha, A., 1984. Ornithogenic soils on King George Island, South Shetland Islands (Maritime Antarctic Zone). Polish Polar Res. 5, 31-60.

Thorn, C., Darmody, R., Dixon, J., Schlyter, P., 2001. The chemical weathering regime of Kärkevagge, arctic-alpine Sweden. Geomorphology.

Ugolini, F.C., 1972. Ornithogenic soils of Antarctica. In: Llano, G.A. (Ed.), Antactic Terrestrial Biology. American Geophysical Union, Washington, D.C., pp. 181-193. http://dx.doi.org/10.1002/9781118664667.ch9.

Ugolini, F.C., Corti, G., Certini, G., 2006. Pedogenesis in the sorted patterned ground of Devon Plateau. Geoderma 136, 87-106. http://dx.doi.org/10.1016/j.geoderma. 2006.03.030.

Vera, M.L., 2011. Colonization and demographic structure of Deschampsia Antarctica and Colobanthus quitensis along an altitudinal gradient on Livingston Island, South Shetland Islands, Antarctica. Polar Res. 30, 1-10. http://dx.doi.org/10.3402/polar. v30i0.7146.

Victoria, F.D.C., Albuquerque, M.P., Pereira, A.B., Simas, F.N.B., Spielmann, A.A. Schaefer, C.E.G.R., 2013. Characterization and Mapping of Plant Communities at Hennequin. vol. 1. pp. 1-10 (doi:polar.v32i0.19261).

Vieira, G., Bockheim, J., Guglielmin, M., Balks, M., Abramov, A.A., Boelhouwers, J., Cannone, N., Ganzert, L., Gilichinsky, D.A., Goryachkin, S., López-Martínez, J., Meiklejohn, I., Raffi, R., Ramos, M., Schaefer, C., Serrano, E., Simas, F., Sletten, R., Wagner, D., 2010. Thermal state of permafrost and active-layer monitoring in the Antarctic: advances during the international polar year 2007-2009. Permafr. Periglac. Process. 21, 182-197. http://dx.doi.org/10.1002/ppp.685.

Wadham, J.L., De'ath, R., Monteiro, F.M., Tranter, M., Ridgwell, A., Raiswell, R., Tulaczyk, S., 2013. The potential role of the Antarctic Ice Sheet in global biogeochemical cycles. Earth Environ. Sci. Trans. R. Soc. Edinb. 104, 55-67. http:// dx.doi.org/10.1017/S1755691013000108.

Walkley, A., Black, I.A., 1934. An examination of the Degtjareff method for determining organic carbon in soils: effect of variation in digestion conditions and of inorganic soil constituents. Soil Sci. 63, 251-263.

Watcham, E.P., Bentley, M.J., Hodgson, D.A., Roberts, S.J., Fretwell, P.T., Lloyd, J.M., Larter, R.D., Whitehouse, P.L., Leng, M.J., Monien, P., Moreton, S.G., 2011. A new Holocene relative sea level curve for the South Shetland Islands, Antarctica. Quat. Sci. Rev. 30, 3152-3170. http://dx.doi.org/10.1016/j.quascirev.2011.07.021.

Wild, A., 1993. Soils and the Environment: An Introduction. Cambridge University Press, New York.

Woronko, B., Hoch, M., 2011. The development of frost-weathering microstructures on sand-sized quartz grains: examples from Poland and Mongolia. Permafr. Periglac. Process. 22, 214-227. http://dx.doi.org/10.1002/ppp.725.

Woronko, B., Pisarska-Jamrozy, M., 2016. Micro-scale frost weathering of sand-sized quartz grains. Permafr. Periglac. Process. 27, 109-122. http://dx.doi.org/10.1002/ ppp.1855.

Yuan, L., Sun, L., Long, N., Xie, Z., Wang, Y., Liu, X., 2010. Seabirds colonized NyÅlesund, Svalbard, Arctic 9,400 years ago. Polar Biol. 33, 683-691. http://dx.doi. org/10.1007/s00300-009-0745-8.

Ziółek, M., Melke, J., 2014. The impact of seabirds on the content of various forms of phosphorus in organic soils of the Bellsund coast, western Spitsbergen. Polar Res. 33, 1-12. http://dx.doi.org/10.3402/polar.v33.19986. 